\title{
Ceramic Morphological Organisation in the Southern Caddo Area: The Clarence H. Webb Collections
}

\author{
Robert Z. Selden, Jr. ${ }^{\mathrm{a}, \mathrm{b}, \mathrm{c}^{*}}$ \\ ${ }^{a}$ Center for Regional Heritage Research, Stephen F. Austin State University, US \\ ${ }^{b}$ Cultural Heritage Department, Jean Monnet University, FR \\ ${ }^{c}$ ORCID ID 0000-0002-1789-8449
}

\begin{abstract}
Analyses of ceramic vessel shape are neither new or novel; however, the relatively recent adoption of geometric morphometric (GM) methods by archaeologists provides a preview of the contribution of GM to the systematic and rigorous study of morphology as applied to material culture. This study is focused upon an analysis of Caddo bottle shapes for Belcher Engraved, Hickory Fine Engraved, Keno Trailed, Smithport Plain, and Taylor Engraved vessels from the Allen Plantation, Belcher Mound, Gahagan Mound, and Smithport Landing sites in the Clarence $\mathrm{H}$. Webb collections from northwest Louisiana. Results indicate some significant relationships between bottle shape and size (allometry), bottle shape and type, and bottle shape and site. A test of morphological integration indicates that the bottles are significantly integrated, meaning that those discrete traits used to characterise their shape (rim, neck, body, and base) vary in a coordinated manner. It also highlights significant integration between the rim and base, and significant integration between the neck and body for this sample. The Smithport Plain and Hickory (Fine) Engraved bottles found at the Belcher Mound, Smithport Landing, and Gahagan Mound sites also provide evidence for two discrete (north-south) base and body shapes.

Keywords: American Southeast, 3D, geometric morphometrics, morphological disparity, morphological integration, virtual archaeology
\end{abstract}

\footnotetext{
${ }^{*}$ Corresponding author, (zselden@sfasu.edu)
} 
The study of form may be descriptive merely, or it may become analytical. We begin by describing the shape of an object in the simple words of common speech: we end by defining it in the precise language of mathematics; and the one method tends to follow the other

$5 \quad$ in strict scientific order and historical continuity (Thompson, 1917).

\section{Caddo bottle shape}

The vagaries associated with the analysis of ceramic vessel shapes have long consumed analysts (Anderson, 1990; Bingham, 1915; Cooper, 1999; Culbert, 1993; Smith Jr., 1985), while the rigorous explication of Caddo vessel shapes has long been a topic of considerable interest (Turpin et al., 1976; Turpin \& Neely, 1977). In addition to vessel shape, it has also been observed that a greater number of small vessels were included in adolescent sepultures (Perttula, 2000), hinting at the possible utility for analyses of allometry.

Defined as "a vessel with a spheroid or oval body, surmounted by a slender,

15 cylindrical neck," Caddo bottles were initially seen as a somewhat homogeneous ceramic form (Harrington, 1920, 187); some with shapes and decorative motifs so similar that they were deemed to be the work of a single maker (Harrington, 1920, 188). Utility ware bottles consisted of simple bottle forms that were plain and unpolished, likely designed to meet performance needs with a coarser paste, rougher surface treatment, and thicker walls on the body than the fine wares (Perttula, 2017, 32). Harrington (1920, Plate LXXI) notes considerable variation in the size of Caddo bottles, an assertion later confirmed by Jackson $(1934,45)$, who divided Caddo bottles into three groups based upon their size. Further, Harrington (1920, Plate XCV) proposed that some bottles may have been produced using a gourd or existing bowl as a mould.

Krieger $(1947,147)$ posited a similarity in bowl shape between the Texarkana and (possibly) McCurtain foci (now phases), and those at Pecos during Glaze periods III to V. Additional support for this argument can be seen in his prior study of Caddo carinated bowls (Krieger, 1946, 221-247). While not a direct 
correlation with bottles, if Caddo potters were indeed using existing bowls as a mold for the base and body of hand-built ceramics as suggested by Harrington (1920), it is possible that Caddo bottles - as well as the many other ceramic shapes - may bear additional evidence that might be used to test that hypothesis.

Caddo vessel forms vary through time and among groups, and reflect stylistic, functional, and social change (Perttula, 2010). Elevated to a high art by female potters (Swanton, 1942), Caddo ceramics "had no superiors short of the Pueblo country" (Swanton, 1942, 239), leading some to posit that Caddo bottles rest at the apex of Native American ceramic technology (Gadus, 2013). A 40 recent evaluation of Caddo vessel shapes proposes a division of the Caddo bottle category into 27 shapes for the northeast Texas region; each with distinct temporal and spatial distributions (Perttula, 2015, Figure 2). Novel deployments of geographic information systems are also aiding in the refinement of the probable geographic extents for known types based upon decorative motifs (McKinnon, 45 2011).

This analysis capitalises upon geometric morphometric tools to highlight the differences, similarities, and a perceived gradual shift toward standardisation associated with a sample of 26 bottles from the collections of Dr. Clarence H. Webb. Included in the analysis is a test of morphological disparity (Wills, 2001)

so used to posit standardisation, and a test of morphological integration (Adams \& Collyer, 2016) that is used to evaluate whether the discrete components of the bottles (rim, neck, body, and base) vary in a coordinated manner.

\subsection{Geometric morphometrics in archaeology}

Analyses of artefact shape are neither new or novel (Okumura \& Araujo, 55 2018), and it is not surprising that geometric morphometrics (GM) (sensu Corti (1993)) has captivated analysts of material culture due to the substantive contribution of morphology to lithic (Fox, 2015; Thulman, 2012; Wilczek et al., 2015) and ceramic typologies (Girrulat, 2006; Topi et al., 2017; Wilczek et al., 2014), additional categories of material culture (Chitwood, 2014; Ros et al., 
2014; Windhager et al., 2012) and novel applications (Barceló, 2010; Lenardi \& Merwin, 2010). Applications of GM in archaeology began with an analysis of irregular shapes by elliptic Fourier analysis (EFA) (Gero \& Mazzullo, 1984), and iterative methodological improvements continue to expand the potential for analyses of shape as it relates to material culture (Figure 1).

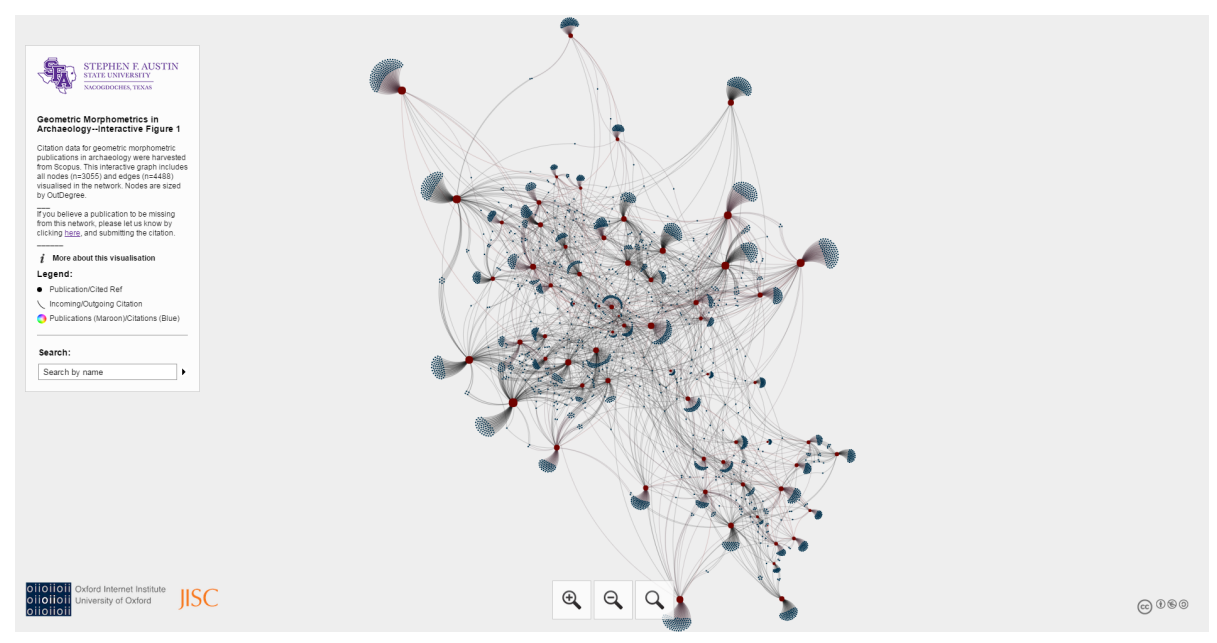

Figure 1: Interactive citation network for geometric morphometric studies in archaeology http://crhr-archive.sfasu.edu/GMArchFig1/.

EFA has been increasingly employed in lithic (Cardillo, 2010; Costa, 2010; Fox, 2015; Ioviţă, 2009, 2010, 2011; Ioviţă \& McPherron, 2011; Smith et al., 2014) and ceramic analyses (Wilczek et al., 2014), where analysts continue to develop new approaches that advance archaeological applications (Gingerich et al., 2014; Sholts et al., 2012; Wilczek et al., 2015). Creative research designs are also being developed and adapted to address some of the very real challenges associated with the oft-fractured and incomplete specimens abundant in the archaeological record (Byrne et al., 2016; Rezek et al., 2011; Smith, 2010; Smith \& DeWitt, 2016; Smith \& Goebel, 2018). These advancements have helped to address challenges with interpretation, while simultaneously aiding in the development of a useful suite of protocols applicable to wide-ranging research questions. 
The more recent fluorescence of landmark-based applications has been driven by advances in anthropology (Bookstein et al., 2004; Elewa, 2010; Richtsmeier et al., 1992; Slice, 2007) and a wide range of other research domains (Adams so et al., 2004, 2013; Bookstein, 1982, 1991, 2016; Jensen, 2003; MacLeod, 2017; Marcus et al., 1996; Rohlf, 1990, 1999; Rohlf \& Marcus, 1993; Rohlf \& Slice, 1990; Zelditch et al., 2004) that articulate with the rise of the Procrustes paradigm (Adams et al., 2013, 8). Archaeological applications have included two-dimensional (2D) analyses of Clovis technology in North America (Buchanan

${ }_{85}$ \& Collard, 2010; Buchanan et al., 2011, 2013, 2015; Eren et al., 2015), Fishtail or Fell projectile points in South America (Castiñeira et al., 2011; Loponte et al., 2015), bifacial points from the Umbu Tradition in Brazil (Okumura \& Araujo, 2013, 2014, 2017), lanceolate points-ayampitin-from Argentina (Rivero \& Heider, 2017), the size and shape of projectile points from southern Patagonia

90 (Charlin \& González-José, 2012; Charlin et al., 2014), bifacial tools from southern Poland (Serwatka, 2015), Final Palaeolithic large tanged points (Serwatka \& Riede, 2016), Paleoindian point types from Florida (Thulman, 2012) and the Southern High Plains (Buchanan et al., 2007, 2017), ceramics from Casas Grandes (Topi et al., 2017), flake morphology (Picin et al., 2014), and reduction 95 effects (de Azevedo et al., 2014); all of which capitalise on the morphological variation that occurs in a single plane (Buchanan \& Collard, 2010; Velhagen \& Roth, 1997).

For research designs that incorporate questions associated with more complex geometry, 3D landmark-based approaches may be more appropriate. Examples from the literature include the development of novel tools and applications (Lycett et al., 2006), and cover a broad range of artefact categories including projectile points (Shott, 2011; Shott \& Trail, 2010), bifaces (Archer \& Braun, 2010; Archer et al., 2015, 2016), percussive tools (Caruana et al., 2014), flake scars (Sholts et al., 2012), flake tools (Archer et al., 2017), handaxes (Lycett, 2009; Lycett et al., 2010, 2015; Lycett \& von Cramon-Taubadel, 2013; Wang et al., 2012), and Caddo ceramics (Selden Jr. et al., 2014). This study enlists the variation that occurs within a single plane for an aggregated sample 
of Caddo bottles; however, 3D data were required to identify the widest vessel profile. Additionally, a variety of landmark and semilandmark configurations are in development that will allow for a more robust analysis of 3D morphology associated with specific elements of vessel morphology.

\subsection{Caddo bottles from Louisiana in the Clarence H. Webb collections}

The sample of Caddo bottles used in the analysis (Table 1) comes from the collections of the late Clarence H. Webb, and were excavated at the Gahagan 115 Mound (16RR1) (Webb \& Dodd, 1939), Smithport Landing (16DS4) (Webb, 1963), Allen Plantation (16NA6) (Webb, 1996), and Belcher Mound (16CD13) (Webb \& Dodd Jr., 1941; Webb, 1959) sites in Northwest Louisiana (Figure 2). Some of Webb's collections were previously repatriated to the Caddo Nation of Oklahoma, but many remain in the collections of the Williamson Museum at 120 Northwestern State University, the Louisiana State Exhibit Museum, and the Louisiana State University (LSU) Museum of Natural Science. Caddo ceramic types in the sample include Belcher Engraved (ca. CE 1200-1500) (Suhm \& Jelks, 1962, 9, and Plate 5), Hickory Fine Engraved (ca. CE 500-1000) (Suhm \& Jelks, 1962, 71, and Plate 36), Keno Trailed (ca. CE 1400-1700) (Suhm \& Jelks, 1962, 87, and Plate 44), Smithport Plain (ca. CE 500-1200) (Suhm \& Jelks, 1962, 145, and Plate 73), and Taylor Engraved (ca. CE 1200-1500) (Suhm \& Jelks, 1962, 149-151, and Plates 75-76).

All bottles used in this analysis fall under the purview of the Native American Graves Protection and Repatriation Act (NAGPRA) (Webb, 1996), excepting those found in House 6 at the Belcher Mound site (Table 1). Permission to scan the collection was granted by the Caddo Nation of Oklahoma with the provision that any scan data used in the analysis must not include the texture (colour) file. Full-resolution scan data were forwarded to the Caddo Nation of Oklahoma with the texture applied. This provides the Caddo with an accurate 3D record of each vessel, and a means of viewing a collection that is currently curated across numerous repositories, making it challenging to locate and aggregate. 
Table 1: Caddo bottles used in the analysis.

\begin{tabular}{|c|c|c|c|c|c|}
\hline Webb No & Site Name & Trinomial & Context & Museum & Type \\
\hline 95 & Smithport Landing & 16DS4 & Burial 1 & $\mathrm{NSU}$ & Smithport Plain \\
\hline 96 & Smithport Landing & 16DS4 & Burial 1 & NSU & Hickory Fine Engraved \\
\hline 142 & Allen Plantation & $16 \mathrm{NA} 6$ & Unknown & NSU & Hickory Fine Engraved \\
\hline 152 & Smithport Landing & 16DS4 & Burial 10 & NSU & Smithport Plain \\
\hline No \# & Smithport Landing & $16 \mathrm{DS} 4 ?$ & Unknown & $\mathrm{NSU}$ & Hickory Fine Engraved \\
\hline 256 & Belcher Mound & 16CD13 & Burial 5 & LSUMNS & Taylor Engraved \\
\hline 267 & Belcher Mound & 16CD13 & Burial 5 & LSEM & Belcher Engraved \\
\hline 269 & Belcher Mound & $16 \mathrm{CD} 13$ & Burial 5 & NSU & Belcher Engraved \\
\hline 271 & Belcher Mound & 16CD13 & Burial 5 & LSUMNS & Taylor Engraved \\
\hline 361 & Belcher Mound & $16 \mathrm{CD} 13$ & Burial 9 & NSU & Belcher Engraved \\
\hline 363 & Belcher Mound & $16 \mathrm{CD} 13$ & Burial 10 & NSU & Belcher Engraved \\
\hline 404 & Belcher Mound & 16CD13 & Burial 11 & NSU & Hickory Fine Engraved \\
\hline $405^{*}$ & Belcher Mound & $16 \mathrm{CD} 13$ & Burial 11 & NSU & Smithport Plain \\
\hline $430^{*}$ & Belcher Mound & 16CD13 & Burial 12 & NSU & Smithport Plain \\
\hline 775 & Belcher Mound & $16 \mathrm{CD} 13$ & Burial 15 & NSU & Belcher Engraved \\
\hline 784 & Belcher Mound & 16CD13 & Burial 15 & LSUMNS & Keno Trailed \\
\hline 787 & Belcher Mound & $16 \mathrm{CD} 13$ & Burial 15 & LSUMNS & Taylor Engraved \\
\hline 788 & Belcher Mound & $16 \mathrm{CD} 13$ & Burial 15 & NSU & Belcher Engraved \\
\hline 803 & Belcher Mound & 16CD13 & Burial 15 & LSUMNS & Belcher Engraved \\
\hline 805 & Belcher Mound & $16 \mathrm{CD} 13$ & Burial 15 & NSU & Belcher Engraved \\
\hline 845 & Belcher Mound & 16CD13 & Burial 17 & NSU & Belcher Engraved \\
\hline 852 & Belcher Mound & $16 \mathrm{CD} 13$ & Burial 17 & NSU & Keno Trailed \\
\hline 897 & Belcher Mound & $16 \mathrm{CD} 13$ & House 6 & $\mathrm{NSU}$ & Belcher Engraved \\
\hline 955 & Gahagan Mound & $16 \mathrm{RR} 1$ & Mound A & $\mathrm{NSU}$ & Hickory Fine Engraved \\
\hline 956 & Gahahan Mound & 16RR1 & Mound A & LSUMNS & Hickory Fine Engraved \\
\hline 997 & Belcher Mound & 16CD13 & Burial 24 & NSU & Belcher Engraved \\
\hline 1054 & Belcher Mound & 16CD13 & Burial 26 & LSEM & Taylor Engraved \\
\hline 1073 & Belcher Mound & 16CD13 & House 6 & $\mathrm{NSU}$ & Belcher Engraved \\
\hline \multicolumn{6}{|c|}{$\begin{array}{l}\text { The single vessel (Hickory Fine Engraved) without a Webb number is assumed to have come } \\
\text { from the Smithport Landing site in fragments. The bottle was later reassembled, but a } \\
\text { number was never assigned. * = only used in the comparison of base/body morphology for } \\
\text { Hickory Fine Engraved and Smithport Plain; NSU = Williamson Museum, Northwestern } \\
\text { State University; LSUMNS = Louisiana State University Museum of Natural Science; } \\
\qquad L S M=\text { Louisiana State Exhibit Museum. }\end{array}$} \\
\hline
\end{tabular}




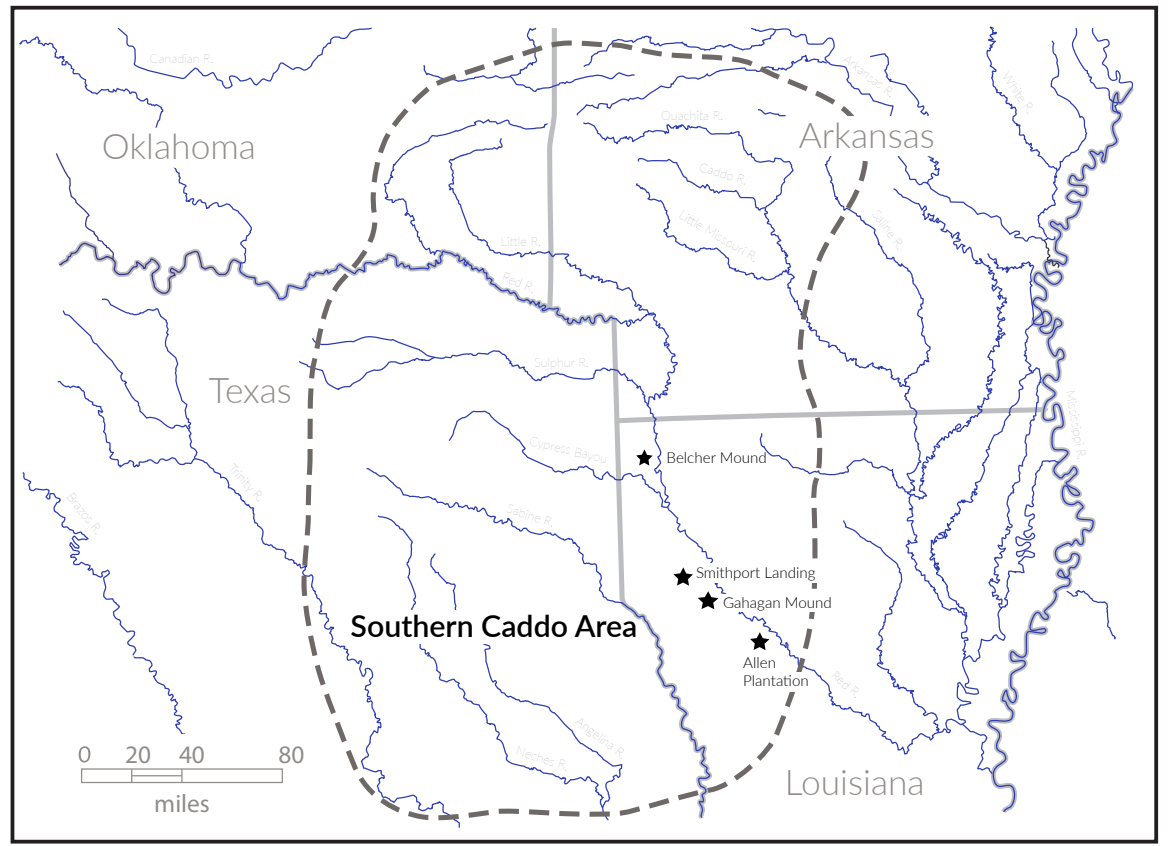

Figure 2: Locations of the Belcher Mound, Mounds Plantation, Smithport Landing, Gahagan Mound, and Allen Plantation sites in northwest Louisiana.

\section{Methods}

Each of the bottles was scanned with a Creaform GoSCAN 50 at a $0.8 \mathrm{~mm}$ resolution in VXelements. Scanner calibration was optimised prior to each scan, with positioning targets required for increased accuracy, and shutter speed reconfigured in each instance. A clipping plane was established to reduce the amount of superfluous data collected during each scan. Following data collection, the resolution of each mesh was increased to $0.5 \mathrm{~mm}$, and the point cloud was transferred to VXmodel where the mesh was rendered following application of the clean mesh function, used to remove isolated patches, self-intersections, spikes, small holes, singular vertices, creased edges, narrow triangles, outcropping triangles, narrow bridges, and non-manifold triangles prior to export as an ASCII stl and ASCII ply. The stl functions as a backup, and the ply was 
subsequently imported to Geomagic Design X (Dx).

points function, by adding a series of 10 points around the circumference of the bottle's base. Each element of reference geometry (vector, point, and plane) was then used in an interactive 3-2-1 alignment where the vessel was aligned to a global origin, orienting it in 3D space where it sits upright atop a planar surface 170 (assumed to be the intent of the maker). Following alignment, the reference plane and point were deleted.

The widest profile was defined as the location on the mesh that lies farthest from that point where the reference vector exits the base while oriented atop the planar surface. To identify that location, a mesh sketch was generated with the 175 the widest vessel circumference. By using the plane at the base of the vessel for the sketch, the point at which the reference vector exits the mesh remains linked to the remainder of the reference geometry. A circle is then sketched using the 
vector as the centre, extending outward until the whole of the vessel fits within. Using the mesh sketch, a cylinder (surface) is extruded around the vessel. The accuracy analyser in Dx is then used to identify the point on the vessel with the lowest deviation from the extruded surface, and a plane (MPlane) is inserted coplanar to the vector and oriented to the widest point, bisecting the vessel at the widest profile.

Using the MPlane as the basis for a second mesh sketch, a spline with 15 interpolation points was sketched on one rim. Above that sketch, a horizontal line was added, then both were used to determine the horizontal tangent of the rim. A vertical line was subsequently added that bisects the rim at the location of the tangent. This operation was repeated for the opposing rim. The logic behind this added step is that the surface scanner cannot reach the interior of the vessel, so the spline needed to be cut in a replicable location. For vessels with a direct (vertical) rim, the preceding step was extended to include one additional measure. A line was drawn between each tangent, then a second from the intersection of the line and reference vector to a point $10 \mathrm{~mm}$ down the vector, where a horizontal line - parallel with the rim peaks - was inserted that intersects with both external walls of the vessel. It is at this intersection that the final mesh sketch was cut to discriminate between the neck and rim.

Using the MPlane as the basis for a third sketch, a spline was populated for the entirety of the silhouetted profile. That spline was split at the horizontal tangent on each rim, and the remaining sections that continued into the bottle interior were deleted. The second split was added at the intersection of the spline and reference vector (centre of base). Four additional splits were added at the juncture of the base/body and body/neck on each side of the vessel at the points of highest curvature. For those bottles with everted rims, the spline was cut at the point of highest curvature between the rim and neck; for those with direct rims, the spline was cut at the intersection of the horizontal line identified in the previous step. The point of highest curvature used to split the spline was identified using the curvature function in Dx, and does not represent an arbitrary location. 
A total of nine landmarks (Table 2) and 46 semilandmarks divide each bottle into four discrete components corresponding with the rim, neck, body, and base (Figure 3). Landmarks and semilandmarks are populated along the spline, always beginning on the side of the profile determined to include the widest point. Divisions between each component articulate with those of the spline splits identified in the previous section, and are based upon specific geometric features where landmarks were placed at each of the points in Table 2 with a series of equidistant semilandmarks between.

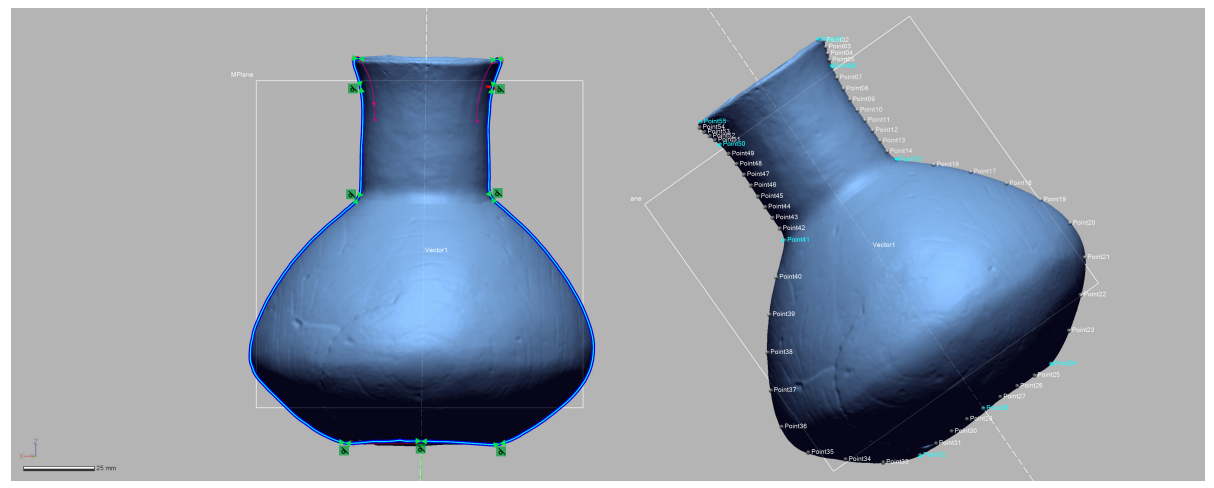

Figure 3: Spline splits for discrete components (rim, neck, body, and base) used in the GM analysis (left) segregated by landmarks (blue), with equidistant semilandmarks (white) populated between (right).

While sliding semilandmarks were an early consideration of this research design, the choice to use equidistant semilandmarks rather than sliding semilandmarks is based upon results from an earlier iteration of this analysis (Figure 4). The first landmark and sliding semilandmark configuration did not split the spline between the neck and rim, and when mean shapes were generated for each type, an anomaly (from the everted rims of the Belcher Engraved bottles) was added to the otherwise direct or tapered necks of the Hickory Fine Engraved and Smithport Plain bottles. Given that the use of sliding semilandmarks could potentially influence the results of this analysis by adding a component of morphology to specimens where it does not exist, they were abandoned. 
Table 2: Landmarks used in this analysis.

\begin{tabular}{|c|c|c|}
\hline Landmark & Location & Definition \\
\hline Point01 & Rim peak & Horizontal tangent of rim curvature on widest side of vessel \\
\hline Point06 & Rim/Neck & $\begin{array}{l}\text { Point of highest curvature (everted rim) or intersection of } \\
\text { horizontal line } 10 \mathrm{~mm} \text { below rim tangents (direct rim) }\end{array}$ \\
\hline Point15 & Neck/Body & Point of highest curvature \\
\hline Point24 & Body/Base & Point of highest curvature \\
\hline Point 28 & CentreBase & Intersection of vector and external surface of $3 \mathrm{D}$ mesh. \\
\hline Point32 & Body/Base & Point of highest curvature \\
\hline Point41 & Neck/Body & Point of highest curvature \\
\hline Point50 & Rim/Neck & $\begin{array}{l}\text { Point of highest curvature (everted rim) or intersection of } \\
\text { horizontal line } 10 \mathrm{~mm} \text { below rim tangents (direct rim) }\end{array}$ \\
\hline Point55 & Rim peak & Horizontal tangent of rim curvature \\
\hline
\end{tabular}

\subsection{Analysis}



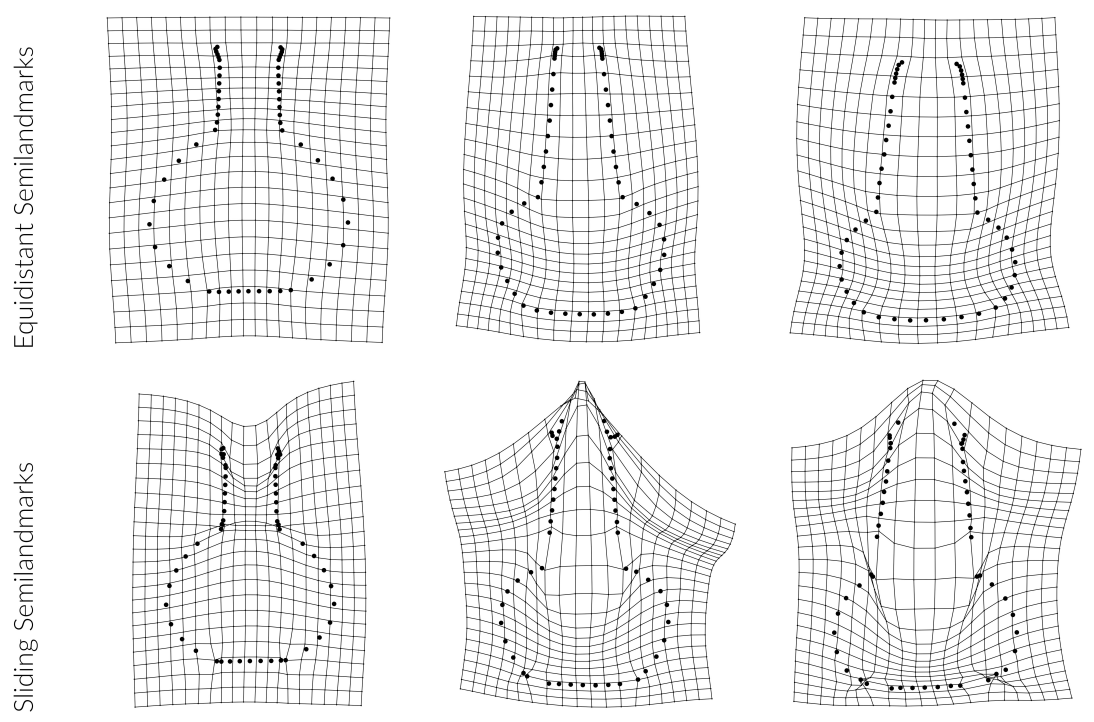

Belcher Engraved

Hickory Fine Engraved

Smithport Plain

Figure 4: Mean consensus configurations for landmarks and equidistant semilandmarks (final analysis; top) and sliding semilandmarks (earlier iteration of analysis; bottom) associated with the Belcher Engraved, Hickory Fine Engraved (HFE), and Smithport Plain (SMPL) types that illustrate a morphological anomaly added to the HFE and SMPL bottles near the rim.

has higher statistical power and a greater ability to identify patterns in the data should they be present (Anderson \& Ter Braak, 2003). To assess whether shape changes with size (allometry), and differs by group (types and sites), Procrustes ANOVAs (Goodall, 1991) were run that also enlist effect-sizes (z-scores) computed as standard deviates of the generated sampling distributions (Collyer et al., 2015). In addition to the Procrustes ANOVA run to assess whether shape changes with size, the assumption of allometric slope homogeneity was tested with the procD.allometry function using the PredLine option (Adams \& Nistri, 2010). Should this test not be significant, then allometric slopes are similar - if not identical - across temporal ranges and types, tested separately.

A Procrustes ANOVA and pairwise test was used to identify sites where bottle shapes differ. The pairwise test is conceptually similar to trajectory analysis 
(Adams \& Collyer, 2007, 2009; Collyer \& Adams, 2007, 2013) in that pairwise is not explicitly needed to contrast vectors between point factor levels nested within group factor levels (Adams et al., 2017). Procrustes variance was used to discriminate between groups and compare the amount of shape variation (morphological disparity) across sites (Zelditch et al., 2004), which is estimated as For the sample of whole vessels, a pairwise comparison of morphological integration was used to test the strength of integration between the four components using a z-score (Adams \& Collyer, 2016).

\section{Results}

The mean consensus configuration and Procrustes residuals were calculated using a Generalised Procrustes Analysis (GPA) for the aggregated sample (Mitteroecker \& Gunz, 2009, Figure 3) (Figure 5). This initial view of the data demonstrates the degree of variability in Caddo bottles that occurs across the sample. As an exploratory measure, GM methods - to include GPA — aid in clar-

275 ifying shape differences, and in the production of novel a posteriori hypotheses (Mitteroecker \& Gunz, 2009).

Principal components analysis (PCA) was conducted on scaled, translated, and rotated landmarks, and demonstrate that the first two PCs account for 63 (PC1) and 22 (PC2) percent of the variation in bottle shape (Table 3 and

28о Figure 6). Together, $\mathrm{PC} 1$ and $\mathrm{PC} 2$ account for 85 percent of shape variation for Caddo bottles, with all remaining PCs representing less than eight percent of the variation (Table 3). The first two PCs are plotted in Figure 6, where warp grids represent the shape changes along PC1. This plot indicates that shape changes associated with $\mathrm{PC} 1$ articulate most readily with neck and body shape. Those shape changes associated with PC2 are dominated by differences in bottle height.

A Procrustes ANOVA was used to test for allometry, and results do indicate 


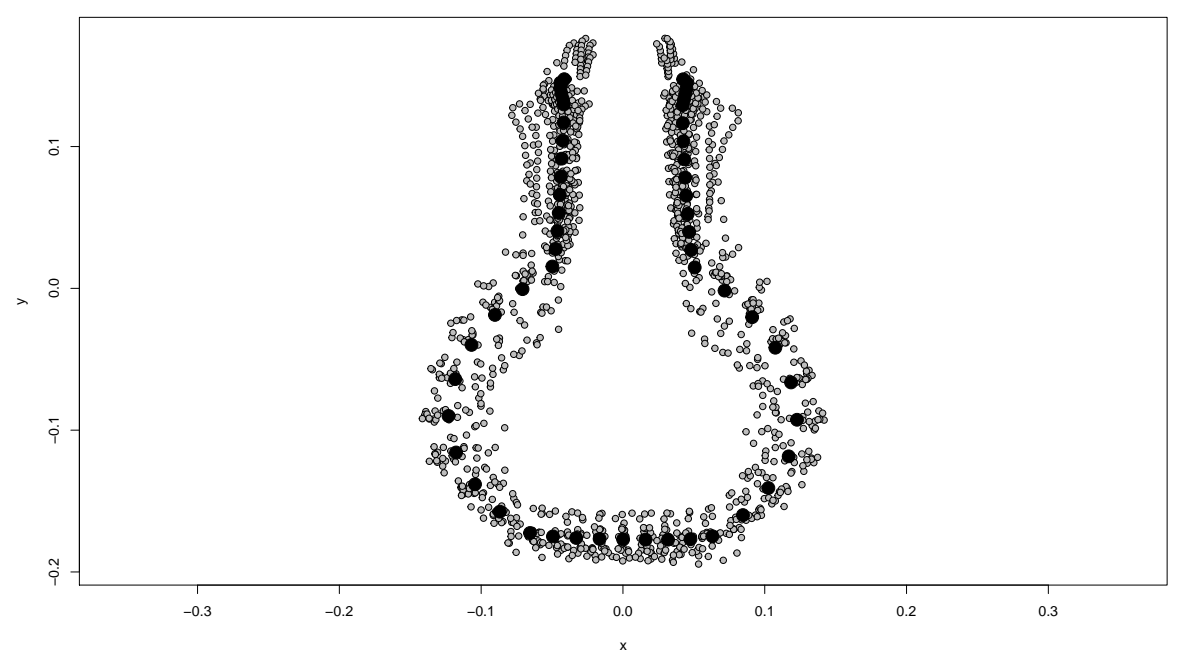

Figure 5: Results of Generalised Procrustes Analysis. Mean consensus configuration shown in black; samples in gray.

Table 3: Results of principal components analysis for first 10 PCs (>99 percent of total variance explained).

\begin{tabular}{llll}
\hline & SD & PVE & CVE \\
\hline PC1 & 0.1028 & 0.6281 & 0.6281 \\
PC2 & 0.0608 & 0.2197 & 0.8478 \\
PC3 & 0.03666 & 0.07989 & 0.92769 \\
PC4 & 0.02242 & 0.02988 & 0.95756 \\
PC5 & 0.01587 & 0.01497 & 0.097253 \\
PC6 & 0.01294 & 0.00995 & 0.98248 \\
PC7 & 0.009728 & 0.005630 & 0.988110 \\
PC8 & 0.007619 & 0.003450 & 0.991560 \\
PC9 & 0.006415 & 0.002450 & 0.994010 \\
PC10 & 0.005605 & 0.001870 & 0.995870 \\
\hline
\end{tabular}

SD - standard deviation; PVE - percentage variance explained; CVE - cumulative variance explained. 

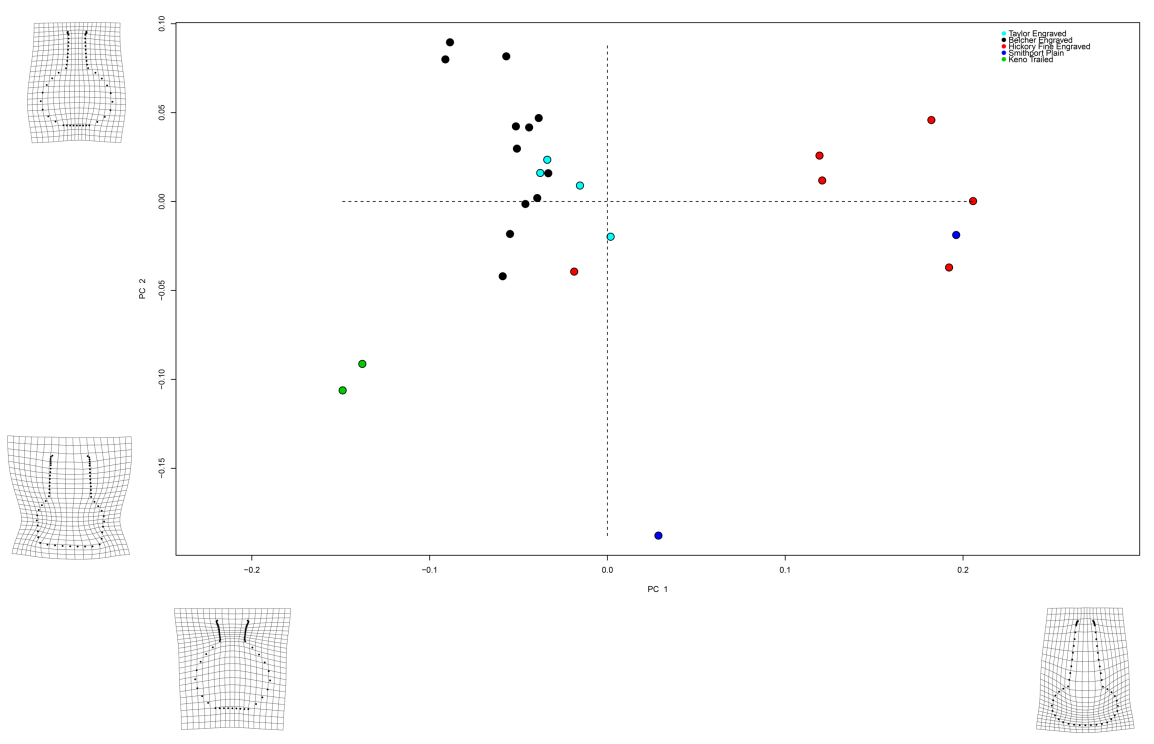

Figure 6: Results of PCA summarising shape variation by type.

significant allometry in this sample $(\mathrm{RRPP}=1000 ; \mathrm{Rsq}=0.27661 ; \operatorname{Pr}(>\mathrm{F})=$ 0.001). Plots of predicted allometric trajectories for temporal (Formative-Early ric trajectory of Formative-Early Caddo bottles (Hickory Fine Engraved and Smithport Plain) differs significantly $(\mathrm{RRPP}=1000 ; \mathrm{Rsq}=0.06143 ; \operatorname{Pr}(>\mathrm{F})$ $=0.001$ ) from that of Late-Historic Caddo bottles (Belcher Engraved, Keno Trailed, and Taylor Engraved) as they increase in size (Figure 7). Allomet$\operatorname{Pr}(>\mathrm{F})=0.001)$ (Figure 7 ), and the size of the Formative-Early bottles, specifically those of the Hickory Fine Engraved type, extends beyond the range of the Late-Historic types.

A Procrustes ANOVA was used to test for a significant difference in bottle 300 shape by site. Results of the ANOVA indicate a significant difference in bottle shape by site $(\mathrm{RRPP}=1000 ; \mathrm{Rsq}=0.6593 ; \operatorname{Pr}(>\mathrm{F})=0.001)$. A pairwise test of shapes was subsequently conducted for groups designated by site. Results confirm a significant difference in bottle shape at the Belcher Mound site when 

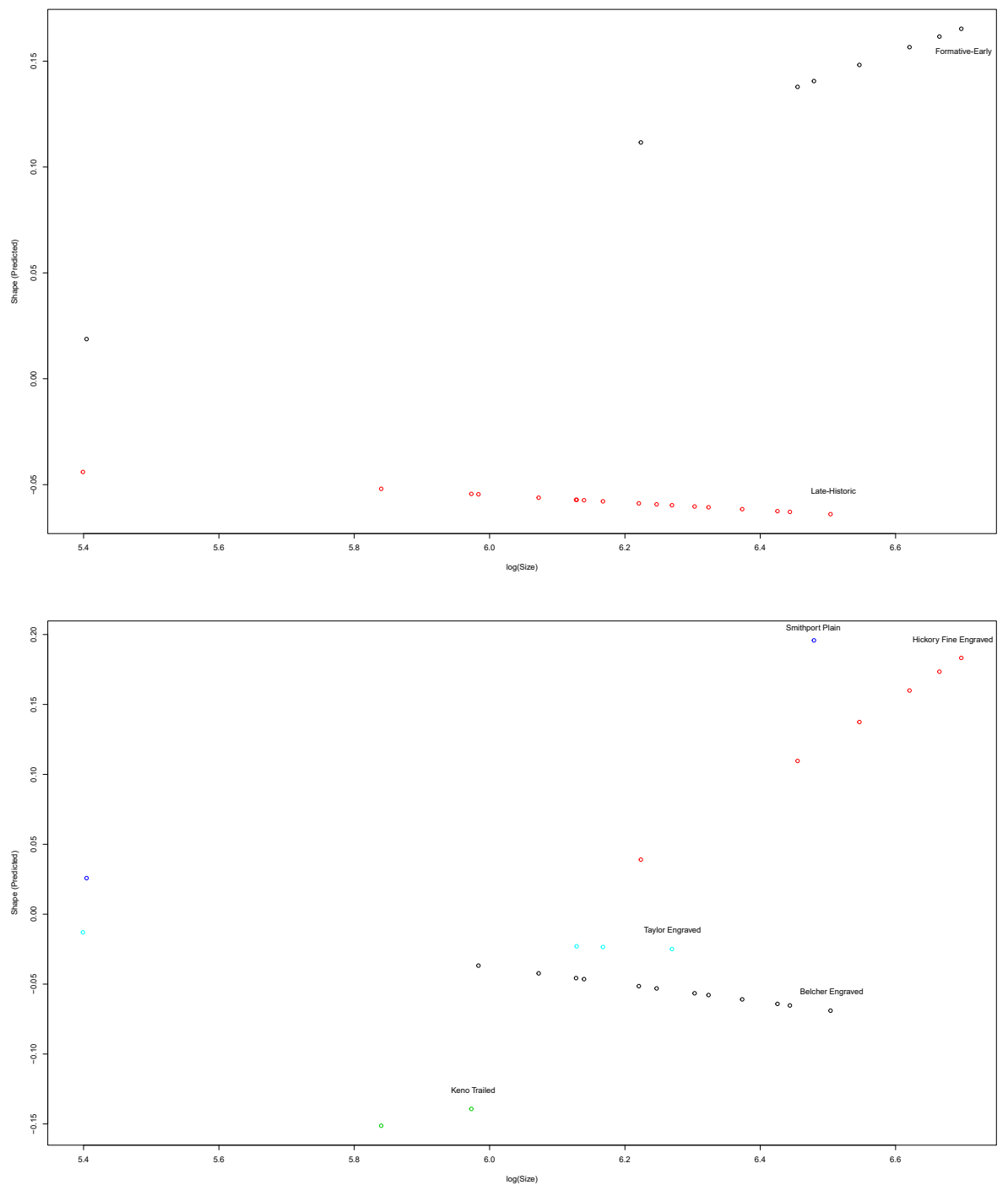

Figure 7: Predicted values of Caddo bottle shape from temporal (top) and type (bottom) regressions versus $\log$ (Centroid Size). 
compared with Gahagan Mound and Smithport Landing (Table 4).

Table 4: P-values and effect sizes for advanced Procrustes ANOVA and pairwise test (RRPP $=1000)$ of shape by site.

\begin{tabular}{lrrrr}
\hline & Allen Pl & Belcher Md & Gahagan Md & Smithport Lnd \\
\hline Allen Plantation & 1.000 & 0.229 & 0.715 & 0.780 \\
& $(0.0000000)$ & $(1.052018)$ & $(-0.68433097)$ & $(-0.87399319)$ \\
Belcher Mound & 0.229 & 1.000 & $\mathbf{0 . 0 0 1}$ & $\mathbf{0 . 0 0 1}$ \\
& $(1.0520179)$ & $(0.000000)$ & $(4.30912352)$ & $(4.69094927)$ \\
Gahagan Mound & 0.715 & $\mathbf{0 . 0 0 1}$ & 1.000 & 0.455 \\
& $(-0.6843310)$ & $(4.309124)$ & $(0.00000000)$ & $(-0.02297927)$ \\
Smithport Landing & 0.780 & $\mathbf{0 . 0 0 1}$ & 0.455 & 1.000 \\
& $(-0.8739932)$ & $(4.690949)$ & $(-0.02297927)$ & $(0.00000000)$ \\
\hline
\end{tabular}

Significant results in bold; effect sizes (z) listed in parentheses.

305 bottle types (Table 5 and Figure 8). Results indicate that Belcher Engraved bottle shape differs significantly from Hickory Fine Engraved, Keno Trailed, and Smithport Plain bottle shape. Taylor Engraved bottles only differ significantly from Hickory Fine Engraved bottle shape, which differ significantly from Belcher Engraved and Keno Trailed. The two Formative-Early Caddo bottle types thus express similarities in shape. The Belcher Engraved and Taylor Engraved bottles from the Late-Historic Caddo period do not differ significantly, and include similar bottle shapes with divergent allometric trajectories as vessel size increases (Figure 7).

A test of morphological disparity indicates that Hickory Fine Engraved and Smithport Plain bottles display a greater range of shape variation among individuals relative to other groups, and differ significantly from the Belcher Engraved, Keno Trailed, and Taylor Engraved bottles (Table 6). Thus, the Formative-Early Caddo bottles encompass a greater range of morphological variability than the Late-Historic Caddo bottles in the sample.

A test of morphological integration for the aggregated sample reveals significant integration (1000 random permutations; r-PLS $=0.883 ;$ P-value $=0.001)$, 
Table 5: P-values and effect sizes for advanced Procrustes ANOVA and pairwise test (RRPP $=1000)$ of shape by type.

\begin{tabular}{lrrrrr}
\hline & Belcher Eng & Hickory FE & Keno Tr & Smithport Pl & Taylor Eng \\
\hline Belcher Eng & 1.000 & $\mathbf{0 . 0 0 1}$ & $\mathbf{0 . 0 4 1}$ & $\mathbf{0 . 0 0 6}$ & 0.757 \\
& $(0.0000000)$ & $(5.0753316)$ & $(2.158402)$ & $(3.3304742)$ & $(-0.7706873)$ \\
Hickory FE & $\mathbf{0 . 0 0 1}$ & 1.000 & $\mathbf{0 . 0 0 1}$ & 0.282 & $\mathbf{0 . 0 1 8}$ \\
& $(5.0753316)$ & $(0.0000000)$ & $(4.975588)$ & $(0.4314228)$ & $(2.5527396)$ \\
Keno Tr & $\mathbf{0 . 0 4 1}$ & $\mathbf{0 . 0 0 1}$ & 1.000 & $\mathbf{0 . 0 1 2}$ & 0.065 \\
& $(2.1584018)$ & $(4.9755878)$ & $(0.000000)$ & $(2.8096335)$ & $(1.6590595)$ \\
Smithport Pl & $\mathbf{0 . 0 0 6}$ & 0.282 & $\mathbf{0 . 0 1 2}$ & 1.000 & 0.063 \\
& $(3.3304742)$ & $(0.4314228)$ & $(2.809633)$ & $(0.0000000)$ & $(1.7108783)$ \\
Taylor Eng & 0.757 & $\mathbf{0 . 0 1 8}$ & 0.065 & 0.063 & 1.000 \\
& $(-0.7706873)$ & $(2.5527396)$ & $(1.659059)$ & $(1.7108783)$ & $(0.0000000)$ \\
\hline
\end{tabular}

Significant results in bold; effect sizes (z) listed in parentheses.

Table 6: P-values and pairwise absolute differences between variances for a test of morpho$\underline{\text { logical disparity }(\mathrm{RRPP}=1000)}$.

\begin{tabular}{lrrrrr}
\hline & Belcher Eng & Hickory FE & Keno Tr & Smithport Pl & Taylor Eng \\
\hline Belcher Eng & 1.000 & $\mathbf{0 . 0 5 2}$ & 0.836 & $\mathbf{0 . 0 2 0}$ & 0.775 \\
& $(0.0000000000)$ & $(0.006004030)$ & $(0.0009198292)$ & $(0.013479467)$ & $(0.001206460)$ \\
Hickory FE & $\mathbf{0 . 0 5 2}$ & 1.000 & 0.133 & 0.142 & 0.239 \\
& $(0.0060040304)$ & $(0.000000000)$ & $(0.0069238596)$ & $(0.007475437)$ & $(0.004797570)$ \\
Keno Tr & 0.836 & 0.133 & 1.000 & $\mathbf{0 . 0 2 5}$ & 0.618 \\
& $(0.0009198292)$ & $(0.006923860)$ & $(0.0000000000)$ & $(0.014399297)$ & $(0.002126289)$ \\
Smithport Pl & $\mathbf{0 . 0 2 0}$ & 0.142 & $\mathbf{0 . 0 2 5}$ & 1.000 & $\mathbf{0 . 0 3 4}$ \\
& $(0.0134794674)$ & $(0.007475437)$ & $(0.0143992965)$ & $(0.000000000)$ & $(0.012273007)$ \\
Taylor Eng & 0.775 & 0.239 & 0.618 & $\mathbf{0 . 0 3 4}$ & 1.000 \\
& $(0.0012064601)$ & $(0.004797570)$ & $(0.0021262892)$ & $(0.012273007)$ & $(0.000000000)$ \\
\hline
\end{tabular}

Significant results in bold; pairwise absolute differences between variances in parentheses. 


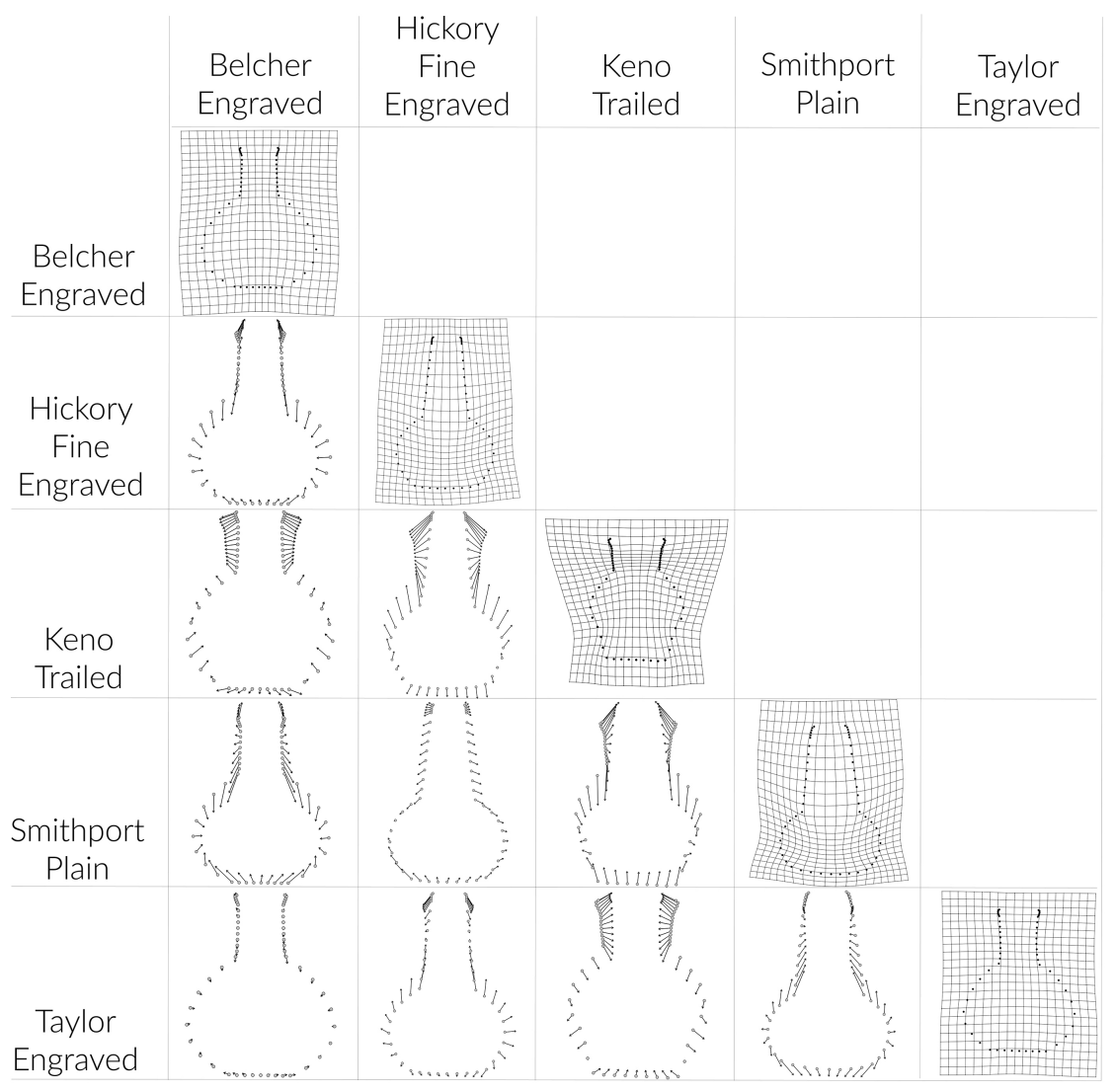

Figure 8: Comparison of mean shapes by type.

indicating that the discrete traits (rim, neck, body, and base) used in the manufacture of Caddo bottles vary in a coordinated manner. A pairwise test of morphological integration was used to identify which traits can be said to covary. Results indicate that for this sample of Caddo bottles, the rim and base are significantly integrated, and that the neck and body are significantly integrated (Table 7).

\subsection{Hickory Fine Engraved and Smithport Plain base/body comparison}

Visual inspection of the 10 Hickory Fine Engraved and Smithport Plain vessels indicate two distinct bottle forms for these types that occur between 
Table 7: P-values and effect sizes for morphological integration by trait (rim $[\mathrm{A}]$, neck $[\mathrm{B}]$, body [C], and base [D]) based on 1000 random permutations.

\begin{tabular}{ccccccc}
\hline & AB.int & AC.int & AD.int & BC.int & BD.int & CD.int \\
\hline \multirow{2}{*}{ AB.int } & 1.00000000 & 0.27409817 & $\mathbf{0 . 0 2 2 2 0 4 6 3}$ & 0.31107177 & 0.1602111 & 0.09225511 \\
& $(0.0000000)$ & $(0.6004651)$ & $(2.0102073)$ & $(0.4928147)$ & $(0.9935906)$ & $(1.3269954)$ \\
AC.int & 0.27409817 & 1.00000000 & 0.06794345 & 0.45439429 & 0.3279348 & 0.21815349 \\
& $(0.6004651)$ & $(0.0000000)$ & $(1.4912842)$ & $(0.1145667)$ & $(0.4456230)$ & $(0.7784446)$ \\
AD.int & $\mathbf{0 . 0 2 2 2 0 4 6 3}$ & 0.06794345 & 1.00000000 & $\mathbf{0 . 0 5 4 1 1 4 5 9}$ & 0.1655456 & 0.24522367 \\
& $(2.0102073)$ & $(1.4912842)$ & $(0.0000000)$ & $(1.6062036)$ & $(0.9719185)$ & $(0.6895975)$ \\
BC.int & 0.31107177 & 0.45439429 & $\mathbf{0 . 0 5 4 1 1 4 5 9}$ & 1.00000000 & 0.2897292 & 0.18639410 \\
& $(0.4928147)$ & $(0.1145667)$ & $(1.6062036)$ & $(0.0000000)$ & $(0.5541759)$ & $(0.8912628)$ \\
BD.int & 0.16021110 & 0.32793480 & 0.16554555 & 0.28972922 & 1.0000000 & 0.38177146 \\
& $(0.9935906)$ & $(0.4456230)$ & $(0.9719185)$ & $(0.5541759)$ & $(0.0000000)$ & $(0.3008316)$ \\
CD.int & 0.09225511 & 0.21815349 & 0.24522367 & 0.18639410 & 0.3817715 & 1.00000000 \\
& $(1.3269954)$ & $(0.7784446)$ & $(0.6895975)$ & $(0.8912628)$ & $(0.3008316)$ & $(0.0000000)$ \\
\hline \multirow{2}{*}{ Sign } & & &
\end{tabular}

Significant results in bold; effect sizes for pairwise differences in PLS effect size in parentheses.

the southern (Allen Plantation, Gahagan Mound, and Smithport Landing) and northern (Belcher Mound) sites. To test whether a significant difference in base/body morphology exists between the two forms, the Hickory Fine Engraved and Smithport Plain bottles from the previous analysis were analysed with two additional Smithport Plain vessels (Webb 405 and 430) from Burials 11 and 12 at the Belcher Mound site (both with broken necks) (see also Table 1). A subset (base and body) of the same landmarks and equidistant semilandmark configuration used in the previous analysis (landmarks/semilandmarks 15-41) were also used in this test, since the two additional samples are missing sections of the neck and rim. The mean consensus configuration and Procrustes residuals were calculated using a generalised Procrustes analysis (GPA) for the aggregated sample (Figure 9).

Principal components analysis (PCA) was conducted on scaled, translated, and rotated landmarks, and demonstrate that the first two PCs account for 78 (PC1) and 14 (PC2) percent of the variation in bottle body/base shape (Table 


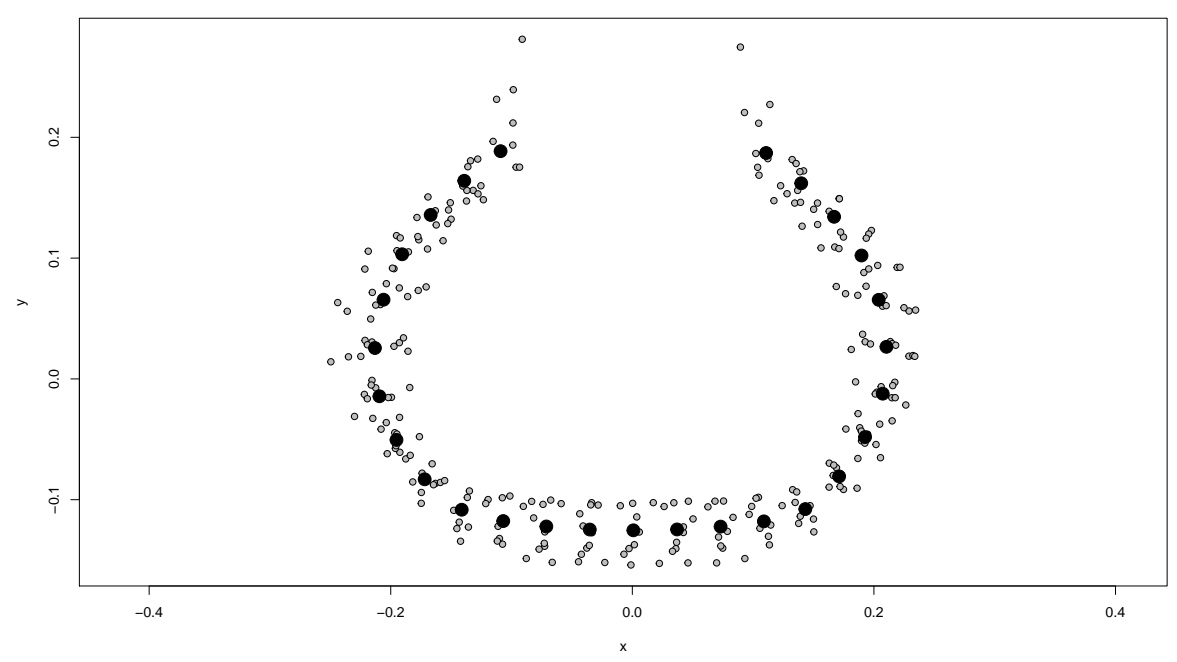

Figure 9: Results of Generalized Procrustes Analysis for the base/body sample. Mean consensus configuration shown in black; samples in gray.

8 and Figure 6). Together, PC1 and PC2 account for 92 percent of shape variation for base/body shape, with all remaining PCs representing less than three percent of the variation (Table 8). The first two PCs are plotted in Figure 6, where warp grids represent the shape changes along PC1. This plot indicates that shape changes associated with $\mathrm{PC} 1$ articulate most readily with height. Those shape changes associated with $\mathrm{PC} 2$ are dominated by differences in bottle width.

A Procrustes ANOVA was used to test for a significant difference in allometry. Results of the ANOVA indicate that allometry in the sample is not significant. A second Procrustes ANOVA was used to test for a significant difference between the two types. Results of the ANOVA indicate that the base/body of the Hickory Fine Engraved and Smithport Plain types do not differ significantly. A third Procrustes ANOVA was used to test for a significant difference in bottle shape by group (North or South). Results of the ANOVA indicate a significant difference in bottle shape by group $(\mathrm{RRPP}=1000 ; \mathrm{Rsq}=0.54538$; $\operatorname{Pr}(>\mathrm{F})=0.0085)$. A pairwise test of shapes was subsequently conducted for 
Table 8: Results of principal components analysis for the nine PCs (100 percent of total variance explained).

\begin{tabular}{llll}
\hline & SD & PVE & CVE \\
\hline PC1 & 0.1261 & 0.7788 & 0.7788 \\
PC2 & 0.05324 & 0.13876 & 0.91755 \\
PC3 & 0.02849 & 0.03975 & 0.95730 \\
PC4 & 0.02473 & 0.02994 & 0.98724 \\
PC5 & 0.01134 & 0.00630 & 0.99354 \\
PC6 & 0.007987 & 0.003120 & 0.996660 \\
PC7 & 0.005782 & 0.001640 & 0.998300 \\
PC8 & 0.005365 & 0.001410 & 0.999710 \\
PC9 & 0.00244 & 0.00029 & 1.00000
\end{tabular}

SD - standard deviation; PVE - percentage variance explained; CVE - cumulative variance explained.

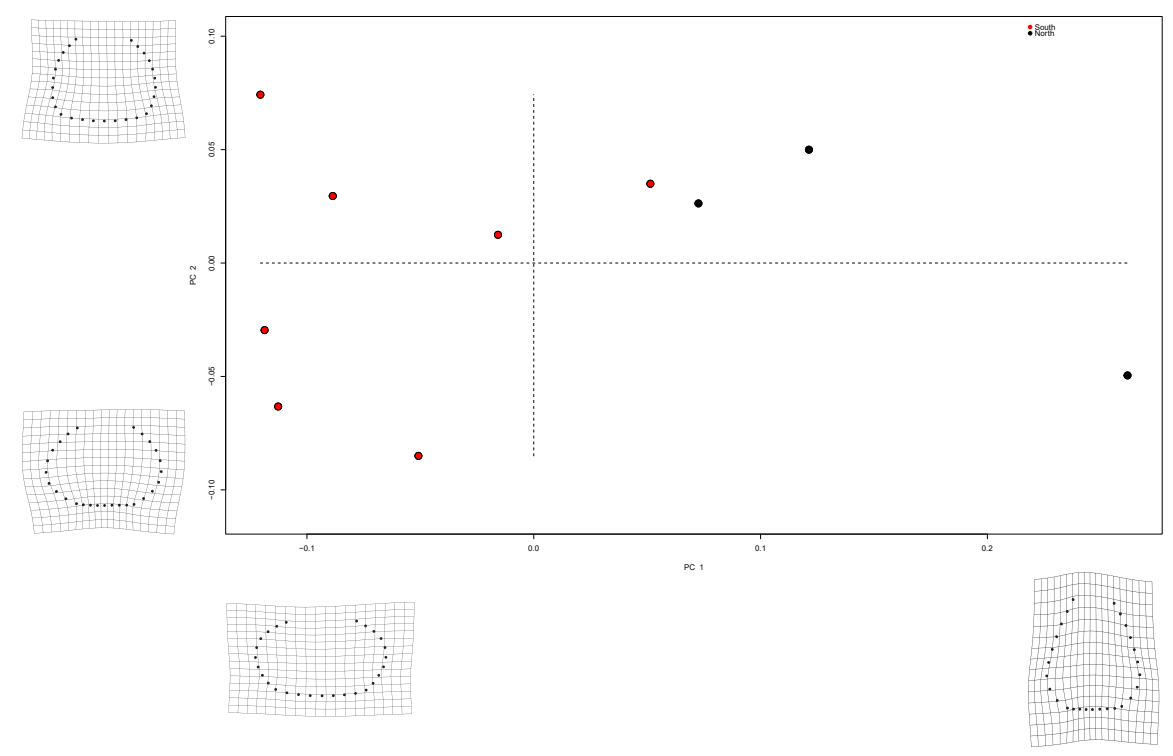

Figure 10: Principal components analysis for Hickory Fine Engraved and Smithport Plain base/body analysis segregated by North-South groups. 
groups designated by group (North or South). Results confirm a significant difference in bottle base/body shape between the Hickory Fine Engraved and Smithport Plain bottles produced at the Belcher Mound site (North) when compared with bottles produced at the Allen Plantation, Gahagan Mound, and Smithport Landing sites (South) (Table 9).

Table 9: P-values and effect sizes for advanced Procrustes ANOVA and pairwise test (RRPP $=1000)$ of shape by group (North and South).

\begin{tabular}{rrr} 
& North & South \\
\cline { 2 - 3 } North & 1.00 & $\mathbf{0 . 0 1}$ \\
& $(0.000000)$ & $(3.141828)$ \\
South & $\mathbf{0 . 0 1}$ & 1.00 \\
& $(3.141828)$ & $(0.000000)$ \\
\hline
\end{tabular}

Significant results in bold; effect sizes (z) listed in parentheses.

\section{Discussion and Conclusion}

This repository-based analysis of a curated and majority-NAGPRA collecnorthwest Louisiana.

The analysis of morphological disparity yielded a significant difference between Formative-Early and Late-Historic Caddo bottle shapes, demonstrating that Formative-Early Caddo bottles occupy a greater range of morphospace 
than Late-Historic Caddo bottles in the sample. While further work is warranted, these results provide evidence that may support an argument for the gradual standardisation of Caddo bottle shapes through time. Whether, and to what extent, that trend may articulate with a potential shift toward craft specialisation is currently unknown. The test of allometry indicates significantly divergent trajectories between Formative-Early and Late-Historic Caddo bottles, and those bottles that do not differ significantly in shape do express differing allometric trajectories. These results also indicate - although based upon a small sample - that Formative-Early bottles extended into a larger size range.

While not explored here, this line of evidence may prove useful in discussions of standardisation (Topi et al., 2017) couched within examinations of craft specialisation (Costin, 1991, 2005; Costin \& Hagstrum, 1995; Rice, 1991; Shepard, 1954). Certainly craft specialisation is not the only theoretical construct that has utility here, and results might also be expressed in discussions of communities of practice and identity (sensu Eckert (2008) and Eckert et al. (2015)), or a wide range of additional approaches; however, the bulk of current archaeological applications of GM enlist evolutionary archaeology (Lycett, 2015; Okumura \& Araujo, 2018).

The shape of Hickory (Fine) Engraved and Smithport Plain bottles in this sample do not differ significantly, and two distinct bottle shapes were found to occur in that population. It is worth noting that the difference in bottle morphology is more dramatic for the Smithport Plain bottles, and the Hickory Fine Engraved shapes may provide clarification regarding a possible morphological transition that occurred across the two types (Figure 10). While the northsouth difference is significant for this sample, the northern sample is informed 410 by a single site (Belcher Mound). The addition of vessels from other areas of the Southern Caddo Area will aid in the continued refinement of those results presented here. More work is needed to better characterise the variation in shape for these bottle types, and to identify the potential shifts in social practices that articulate with the variations in bottle morphology. 
The test of morphological integration for the Caddo bottle sample was significant, meaning that the different components of the bottles (rim, neck, base, and body) vary in a coordinated manner. Further, those traits associated with the rim and base are significantly integrated, as are those associated with the neck and body. Although preliminary, this result provides support for the hypothesis motif, etc.) with morphological data to test for significant relationships. That information, in turn, is a valuable contribution to a wide range of potential interpretations that include the evolution of design and morphology, craft production, the identification of communities of practice and identity, as well as 435 many others.

In addition to their analytical value, those 3D data produced throughout the course of this study have been repurposed as a tool for public archaeology, citizen science, and general outreach. While not all of the bottles have been added, many can be viewed on Sketchfab, and selected vessels are available test and refine settings on a $3 \mathrm{D}$ printer to ensure that the morphology of the printed specimens is as close to the original as possible (Figure 11), providing a means of interacting with an accurate proxy while reducing physical access to the original specimen. Further still, should the Caddo Nation of Oklahoma decide to repatriate this collection, the $3 \mathrm{D}$ meshes would remain a valuable 
tool for comparative analyses long after the originals had been repatriated and reburied.
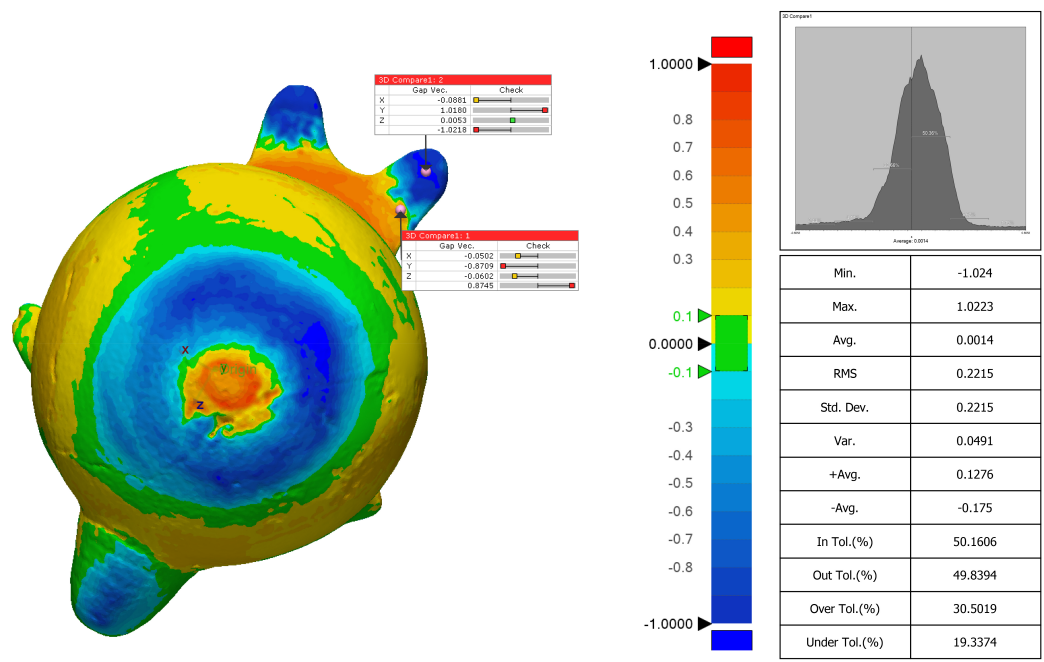

\begin{tabular}{|c|c|}
\hline Product Name & NSU-773 \\
\hline Part Name & 3D Print \\
\hline
\end{tabular}

\begin{tabular}{|c|c|}
\hline Department & CRHR \\
\hline Inspector & Selden \\
\hline
\end{tabular}

\begin{tabular}{|c|c|}
\hline Date & Dec 04,2017 \\
\hline Unit & $\mathrm{mm}$ \\
\hline
\end{tabular}

Figure 11: Computer-aided inspection of the original 3D scan data contrasted with a scan of a $3 \mathrm{D}$ print of the same object. This Caddo effigy vessel is a part of the Webb collection, and comes from the Belcher Mound in northwest Louisiana.

The progression of this analysis will include (1) an expansion of the Hickory (Fine) Engraved and Smithport Plain analysis to explore whether it may be possible to identify the locus of innovation associated with the two bottle shapes found here, as well as whether other bottle shapes that were employed by the Caddo makers of these types, (2) an expansion of the Belcher and Taylor Engraved sample to test whether the similarity in bottle shape identified in this study is localised, (3) continued analyses of morphological disparity among different temporal periods (Formative, Early, Middle, Late, and Historic) to test whether significant morphological disparity and size variation between these time periods varies elsewhere across time and space, and (4) the continued use 
of morphological integration to identify which morphological traits associated with Caddo bottle manufacture might be said to covary. The application of GM methods to questions of Caddo ceramic morphology can produce meaningful results that contribute to the interpretation of Caddo sites, communities, and the possible relationships that existed between them, while simultaneously providing a systematic and rigorous method that archaeologists can use to test a wide range of previous, current, and future hypotheses. Those results presented here provide a preview of that utility, and serve as the foundation for the progression and logical expansion of this research design.

\section{Acknowledgments}

I extend my gratitude to the Caddo Nation of Oklahoma, the Williamson Museum at Northwestern State University (Hiram F. [Pete] Gregory and Jeffrey

470 R. Girard), the Louisiana State Exhibit Museum (Nita Cole), and the LSU Museum of Natural Science (Rebbecca A. Saunders and Beverly S. Nuschler) for the requisite permissions and access needed to generate the 3D scans of the Caddo bottles from the Webb collection. Thanks also to Dean C. Adams, Emma Sherratt, Stephen J. Lycett, Michael J. Shott, Timothy K. Perttula, and

475 Kersten Bergstrom for their constructive criticisms, comments, and suggestions throughout the development of this research design, and to the anonymous reviewers whose comments further improved the manuscript. Development of this analytical work flow and the production of $3 \mathrm{D}$ scans from the Clarence $\mathrm{H}$. Webb collection was funded by a grant to RZS (P14AP00138) from the National 4во Center for Preservation Technology and Training.

\section{References Cited}

Adams, D. C., \& Collyer, M. L. (2007). Analysis of Character Divergence along Environmental Gradients and other Covariates. Evolution, 61, 510-5. URL: https://www.ncbi.nlm.nih.gov/pubmed/17348916. doi:10.1111/j . $485 \quad 1558-5646.2007 .00063 . x$. 
Adams, D. C., \& Collyer, M. L. (2009). A General Framework for the Analysis of Phenotypic Trajectories in Evolutionary Studies. Evolution, 63, 114354. URL: http://www.ncbi.nlm.nih.gov/pubmed/19210539. doi:10.1111/ j.1558-5646.2009.00649.x.

Adams, D. C., \& Collyer, M. L. (2015). Permutation Tests for Phylogenetic Comparative Analyses of High-Dimensional Shape Data: What you Shuffle Matters. Evolution, 69, 823-9. URL: http://www.ncbi.nlm.nih.gov/ pubmed/25641367. doi:10.1111/evo.12596.

Adams, D. C., \& Collyer, M. L. (2016). On the Comparison of the Strength of Morphological Integration across Morphometric Datasets. Evolution, 70, 2623-2631. URL: https://www.ncbi.nlm.nih.gov/pubmed/27592864. doi:10.1111/evo.13045.

Adams, D. C., Collyer, M. L., Kaliontzopoulou, A., \& Sherratt, E. (2017). Package 'geomorph': Geometric Morphometric Analyses of 2D/3D Landmark Data. R package version 3.0.5. URL: http://geomorphr.github.io/ geomorph/.

Adams, D. C., \& Nistri, A. (2010). Ontogenetic Convergence and Evolution of Foot Morphology in European Cave Salamanders (Family: Plethodontidae). BMC Evolutionary Biology, 10, 1-10. URL: https://www.ncbi.nlm.nih. gov/pubmed/20637087. doi:10.1186/1471-2148-10-216.

Adams, D. C., \& Otárola-Castillo, E. (2013). geomorph: An R Package for the Collection and Analysis of Geometric Morphometric Shape Data. Methods in Ecology and Evolution, 4, 393-399. doi:10.1111/2041-210x.12035.

Adams, D. C., Rohlf, F. J., \& Slice, D. E. (2004). Geometric Morphometrics: 510 Ten Years of Progress Following the 'Revolution'. Italian Journal of Zoology, 71, 5-16. doi:10.1080/11250000409356545.

Adams, D. C., Rohlf, F. J., \& Slice, D. E. (2013). A Field Comes of Age: 
Geometric Morphometrics in the 21st Century. Hystrix, 24, 7-14. doi:10. 4404/hystrix-24.1-6283.

515 Anderson, M. J., \& Ter Braak, C. J. F. (2003). Permutation Tests for MultiFactoral Analysis of Variance. Journal of Statistical Computation and Simulation, 73, 85-113. doi:10.1080=0094965021000015558.

Anderson, W. P. (1990). 1. Bulletin of the American Schools of Oriental Research, $279,35-54$

${ }_{520}$ Archer, W., \& Braun, D. R. (2010). Variability in Bifacial Technology at Elandsfontein, Western Cape, South Africa: A Geometric Morphometric Approach. Journal of Archaeological Science, 37, 201-209. doi:10.1016/j.jas.2009. 09.033.

Archer, W., Gunz, P., van Niekerk, K. L., Henshilwood, C. S., \& McPherron, S. P. (2015). Diachronic Change within the Still Bay at Blombos Cave, South Africa. PLoS One, 10, e0132428. URL: http://www.ncbi.nlm.nih.gov/ pubmed/26134976. doi:10.1371/journal . pone.0132428.

Archer, W., Pop, C. M., Gunz, P., \& McPherron, S. P. (2016). What is Still Bay? Human Biogeography and Bifacial Point Variability. Journal of Human Evolution, 97, 58-72. URL: https://www.ncbi.nlm.nih.gov/pubmed/27457545. doi:https://doi.org/10.1016/j.jhevol.2016.05.007.

Archer, W., Pop, C. M., Rezek, Z., Schlager, S., Lin, S. C., Weiss, M., Dogandžić, T., Desta, D., \& McPherron, S. P. (2017). A Geometric Morphometric Relationship Predicts Stone Flake Shape and Size Variability. Archaeological and Anthropological Sciences, . doi:10.1007/s12520-017-0517-2.

de Azevedo, S., Charlin, J., \& González-José, R. (2014). Identifying Design and Reduction Effects on Lithic Projectile Point Shapes. Journal of Archaeological Science, 41, 297-307. doi:10.1016/j.jas.2013.08.013.

Barceló, J. A. (2010). Visual Analysis in Archaeology. An Artificial Intelligence Approach. In A. M. T. Elewa (Ed.), Morphometrics for Nonmorphometricians 
Lecture Notes in Earth Science (pp. 93-156). New York: Springer. doi:10. 1007/978-3-540-95853-6_5.

Bingham, H. (1915). Types of Machu Picchu Pottery. American Anthropologist, $17,257-271$.

${ }_{545}$ Bookstein, F. L. (1982). Foundations of Morphometrics. Annual Review of Ecology and Systematics, 13, 451-470. doi:https://doi.org/10.1146/annurev . es.13.110182.002315.

Bookstein, F. L. (1991). Morphometric Tools for Landmark Data: Geometry and Biology. Cambridge: Cambridge University Press.

Bookstein, F. L. (2016). The Inappropriate Symmetries of Multivariate Statistical Analysis in Geometric Morphometrics. Evolutionary Biology, 43, 277-313. URL: https://www.ncbi.nlm.nih.gov/pubmed/27512236. doi:10. $1007 / \mathrm{s} 11692-016-9382-7$.

Bookstein, F. L., Slice, D. E., Gunz, P., \& Mitteroecker, P. (2004). Anthropology Takes Control of Morphometrics. Collegium Antropologicum, 28, 121-32.

Buchanan, B., \& Collard, M. (2010). A Geometric Morphometrics-Based Assessment of Blade Shape Differences among Paleoindian Projectile Point Types from Western North America. Journal of Archaeological Science, 37, 350-359. doi:10.1016/j.jas.2009.09.047.

Buchanan, B., Collard, M., Hamilton, M. J., \& O'Brien, M. J. (2011). Points and Prey: A Quantitative Test of the Hypothesis that Prey Size Influences early Paleoindian Projectile Point Form. Journal of Archaeological Science, 38, 852-864. doi:10.1016/j.jas.2010.11.007.

Buchanan, B., Eren, M. I., Boulanger, M. T., \& O’Brien, M. J. (2015). Size, 565 Shape, Scars, and Spatial Patterning: A Quantitative Assessment of Late Pleistocene (Clovis) Point Resharpening. Journal of Archaeological Science: Reports, 3, 11-21. doi:http://dx.doi.org/10.1016/j.jasrep. 2015. 05.011. 
Buchanan, B., Johnson, E., Strauss, R. E., \& Lewis, P. J. (2007). A Morphometric Approach to Assessing Late Paleoindian Projectile Point Variability on the Southern High Plains. Plains Anthropologist, 52, 279-299. doi:10.1179/pan.2007.019.

Buchanan, B., O'Brien, M. J., \& Collard, M. (2017). A Geometric Morphometrics-Based Assessment of Point Types on the Southern High Plains during Plainview Times. In V. T. Holliday, E. Johnson, \& R. Knudson (Eds.), Plainview: The Enigmatic Paleoindian Artifact Style of the Great Plains (pp. 274-284). Salt Lake City: University of Utah Press.

Buchanan, B., O’Brien, M. J., \& Collard, M. (2013). Continent-Wide or RegionSpecific? A Geometric Morphometrics-Based Assessment of Variation in Clovis Point Shape. Archaeological and Anthropological Sciences, 6, 145-162. doi:10.1007/s12520-013-0168-x.

Byrne, F., Proffitt, T., Arroyo, A., \& de la Torre, I. (2016). A Comparative Analysis of Bipolar and Freehand Experimental Knapping Products from Olduvai Gorge, Tanzania. Quaternary International, 424, 58-68. doi:https://doi.org/10.1016/j.quaint.2015.08.018.

Cardillo, M. (2010). Some Applications of Geometric Morphometrics to Archaeology. In A. M. T. Elewa (Ed.), Morphometrics for Nonmorphometricians Lecture Notes in Earth Sciences (pp. 325-341). New York: Springer. doi:10.1007/978-3-540-95853-6_15. Archer, W., Bobe, R., \& Harris, J. W. K. (2014). Quantifying Traces of Tool Use: A Novel Morphometric Analysis of Damage Patterns on Percussive Tools. PLoS One, 9, e113856. URL: http://www.ncbi.nlm.nih.gov/ pubmed/25415303. doi:10.1371/journal . pone. 0113856.

${ }_{595}$ Castiñeira, C., Cardillo, M., Charlin, J., \& Baeza, J. (2011). Analisis de Morfometría Geométrica en Puntas Cola de Pescado del Uruguay. Latin American Antiquity, 22, 335-358. doi:10.7183/1045-6635.22.3.335. 
Charlin, J., Cardillo, M., \& Borrazzo, K. (2014). Spatial Patterns in Late Holocene Lithic Projectile Point Technology of Tierra del Fuego (Southern South America): Assessing Size and Shape Changes. World Archaeology, 46, 78-100. URL: <GotoISI>://WOS:000334334200007. doi:10.1080/ 00438243.2014 .890914$.

Charlin, J., \& González-José, R. (2012). Size and Shape Variation in Late Holocene Projectile Points of Southern Patagonia: A Geometric Morphometric Study. American Antiquity, 77, 221-242. doi:10.7183/0002-7316.77.2. 221.

Chitwood, D. H. (2014). Imitation, Genetic Lineages, and Time Influenced the Morphological Evolution of the Violin. PLoS One, 9, e109229. URL: http://www.ncbi.nlm.nih.gov/pubmed/25295734. doi:10.1371/journal. pone. 0109229.

Collyer, M. L., \& Adams, D. C. (2007). Analysis of Two-State Multivariate Phenotypic Change in Ecological Studies. Ecology, 88, 683-692. URL: https : //www.ncbi.nlm.nih.gov/pubmed/17503596. doi:10.1890/06-0727.

Collyer, M. L., \& Adams, D. C. (2013). Phenotypic Trajectory Analysis: Comparison of Shape Change Patterns in Evolution and Ecology. Hystrix, 24, 75-83. doi:doi:10.4404/hystrix-24.1-6298.

Collyer, M. L., \& Adams, D. C. (2018). RRPP: An R Package for Fitting Linear Models to High-Dimensional Data using Residual Randomization. Methods in Ecology and Evolution, . URL: https://besjournals. onlinelibrary.wiley.com/doi/pdf/10.1111/2041-210X.13029. doi:https://doi.org/10.1111/2041-210X.13029.

Collyer, M. L., Sekora, D. J., \& Adams, D. C. (2015). A Method for Analysis of Phenotypic Change for Phenotypes Described by High-Dimensional Data. Heredity, 115, 357-65. URL: http://www.ncbi.nlm.nih.gov/ 625 pubmed/25204302. doi:10.1038/hdy.2014.75. 
Cooper, E. N. (1999). The EB-MB Transitional Period at Tell Kabir, Syria. In G. del Olmo Lete, \& J. L. Montero Fenollôs (Eds.), Archaeology of the Upper Syrian Euphrates. The Tishreen Dam area. Proceedings of the International Symposium held at Barcelona, January 28th-30th 1998. Barcelona: Editorial Ausa volume Aula Orientalis-Supplementa 15.

Corti, M. (1993). Geometric Morphometrics: An Extension of the Revolution. Trends in Ecology 85 Evolution, 8, 302-303. doi:https://doi.org/10.1016/ 0169-5347 (93) 90261-M.

Costa, A. G. (2010). A Geometric Morphometric Assessment of Plan Shape in Bone and Stone Acheulean Bifaces from the Middle Pleistocene Site of Castel di Guido, Latium, Italy. In S. J. Lycett, \& P. R. Chauhan (Eds.), New Perspectives on Old Stones: Analytical Approaches to Paleolithic Technologies (pp. 23-41). New York: Springer. URL: <GotoISI>://WOS : 000389728400002. doi:10.1007/978-1-4419-6861-6_2.

Costin, C. L. (1991). Craft Specialization: Issues in Defining, Documenting, and Explaining the Organization of Production. In M. B. Schiffer (Ed.), Archaeological Method and Theory Vol. 3 (pp. 1-56). Tucson: University of Arizona Press.

Costin, C. L. (2005). Craft Production. In J. D. G. Maschner (Ed.), Handbook ${ }_{645}$ of Archaeological Methods (pp. 1034-1107). Walnut Creek: AltaMira.

Costin, C. L., \& Hagstrum, M. B. (1995). Standardization, Labor Investment, Skill, and the Organization of Ceramic Production in Late Prehispanic Highland Peru. American Antiquity, 60, 619-639. doi:10.2307/282046.

Culbert, T. P. (1993). The Ceramics of Tikal: Vessels from the Burials, Caches, and Problematical Deposits. Philadelphia: Tikal Report No. 25, Part A. University Museum, University of Pennsylvania.

Early, A. M. (2012). Form and Structure in Prehistoric Caddo Pottery Design. 
In T. K. Perttula, \& C. P. Walker (Eds.), The Archaeology of the Caddo (pp. 26-46). Lincoln: University of Nebraska Press.

Eckert, S. L. (2008). Pottery and Practice: The Expression of Identity at Pottery Mound and Hummingbird Pueblo. Albuquerque: University of New Mexico Press.

Eckert, S. L., Schleher, K. L., \& James, W. D. (2015). Communities of Identity, Communities of Practice: Understanding Santa Fe Black-on-White Pottery in the Española Basin of New Mexico. Journal of Archaeological Science, 63, 1-12. doi:10.1016/j.jas.2015.07.001.

Elewa, A. M. T. (2010). Morphometrics for Nonmorphometricians. Lecture Notes in Earth Sciences. New York: Springer. doi:10.1007/ 978-3-540-95853-6.

${ }_{665}$ Eren, M. I., Buchanan, B., \& O'Brien, M. J. (2015). Social Learning and Technological Evolution during the Clovis Colonization of the New World. Journal of Human Evolution, 80, 159-70. URL: https://www.ncbi.nlm.nih.gov/ pubmed/25666759. doi:https://doi.org/10.1016/j.jhevol.2015.01.002.

Fox, A. N. (2015). A Study of Late Woodland Projectile Point Typology in 670 New York using Elliptical Fourier Outline Analysis. Journal of Archaeological Science: Reports, 4, 501-509. doi:10.1016/j.jasrep.2015.10.022.

Gadus, E. F. (2013). Twisted Serpents and Fierce Birds: Structural Variation in Caddo Engraved Ceramic Bottle Motifs. Bulletin of the Texas Archeological Society, 84, 215-247.

675 Gero, J., \& Mazzullo, J. (1984). Analysis of Artifact Shape Using Fourier Series in Closed Form. Journal of Field Archaeology, 11, 315. doi:10.2307/529282.

Gingerich, J. A. M., Sholts, S. B., Wärmländer, S. K. T. S., \& Stanford, D. (2014). Fluted Point Manufacture in Eastern North America: An Assessment of Form and Technology using Traditional Metrics and 3D Digital Mor- 
phometrics. World Archaeology, 46, 101-122. doi:10.1080/00438243.2014. 892437.

Girrulat, I. C. (2006). Contribution of Geometric Morphometrics to the Study of Archaeological Ceramics. Revista Werken, 8, 57-75.

Goodall, C. (1991). Procrustes Methods in the Statistical Analysis of Shape. Journal of the Royal Statistical Society. Series B (Methodological), 53, 285339.

Gower, J. C. (1975). Generalized Procrustes Analysis. Psychometrika, 40, 33-51. doi:https://doi.org/10.1007/BF02291478.

Harrington, M. R. (1920). Certain Caddo Sites in Arkansas. New York: Indian Notes and Monographs, Miscellaneous Series No. 10. Museum of the American Indian, Heye Foundation.

Ioviţă, R. (2009). Ontogenetic Scaling and Lithic Systematics: Method and Application. Journal of Archaeological Science, 36, 1447-1457. doi:10.1016/ j.jas.2009.02.008.

Ioviţă, R. (2010). Comparing Stone Tool Resharpening Trajectories with the Aid of Elliptical Fourier Analysis. In S. J. Lycett, \& P. Chauhan (Eds.), New Perspectives on Old Stones: Analytical Approaches to Paleolithic Technologies (pp. 235-253). New York: Springer-Verlag New York. doi:10.1007/978-1-4419-6861-6_10.

Ioviţă, R. (2011). Shape Variation in Aterian Tanged Tools and the Origins of Projectile Technology: A Morphometric Perspective on Stone Tool Function. PLoS One, 6, e29029. URL: http://www.ncbi.nlm.nih.gov/pubmed/ 22216161. doi:10.1371/journal.pone.0029029.

Ioviţă, R., \& McPherron, S. P. (2011). The Handaxe Reloaded: A Morphometric 705 Reassessment of Acheulian and Middle Paleolithic Handaxes. Journal of Human Evolution, 61, 61-74. URL: http://www.ncbi.nlm.nih.gov/pubmed/ 21496877. doi:10.1016/j.jhevol.2011.02.007. 
Jackson, A. T. (1934). Types of East Texas Pottery. Bulletin of the Texas Archeological and Paleontological Society, 6, 38-57.

Jolliffe, I. T. (2002). Principal Component Analysis. New York: Springer.

Kendall, D. G. (1981). The Statistics of Shape. In V. Barnett (Ed.), Interpreting Multivariate Data (pp. 75-80). New York: Wiley.

Kendall, D. G. (1984). Shape Manifolds, Procrustean Metrics, and Complex Projective Spaces. Bulletin of the London Mathematical Society, 16, 81-121. doi:10.1112/blms/16.2.81.

Klingenberg, C. P. (2013). Visualizations in Geometric Morphometrics: How to Read and How to Make Graphs Showing Shape Changes. Hystrix, 24, 15-24. URL: <GotoISI>://WOS:000330926000003. doi:http://dx.doi. org/10.4404/hystrix-24.1-7691.

Krieger, A. D. (1946). Culture Complexes and Chronology in Northern Texas, with Extensions of Puebloan Datings to the Mississippi Valley volume Publication No. 4640. Austin: The University of Texas.

Krieger, A. D. (1947). The Eastward Extension of Puebloan Datings toward Cultures of the Mississippi Valley. American Antiquity, 12, 141-148. doi:10. $2307 / 275701$.

Lenardi, M. J., \& Merwin, D. E. (2010). Towards Automating Artifact Analysis: A Study Showing Potential Applications of Computer Vision and Morphometrics to Artifact Typology. In A. M. T. Elewa (Ed.), Morphometrics for Nonmorphometricians Lecture Notes in Earth Sciences (pp. 289-306). New York: Springer. doi:10.1007/978-3-540-95853-6_13.

Loponte, D., Okumura, M., \& Carbonera, M. (2015). New Records of Fishtail Projectile Points from Brazil and its Implications for its Peopling. Journal of Lithic Studies, 3. doi:10.2218/j1s.v3i1.1312. 
Lycett, S. J. (2009). Quantifying Transitions: Morphometric Approaches to Palaeolithic Variability and Technological Change. In M. Camps, \& P. Chauhan (Eds.), Sourcebook of Paleolithic Transitions (pp. 79-92). Springer. doi:10.1007/978-0-387-76487-0_5.

Lycett, S. J. (2015). Cultural Evolutionary Approaches to Artifact Variation Over Time and Space: Basis, Progress, and Prospects. Journal of Archaeological Science, 56, 21-31. doi:10.1016/j.jas.2015.01.004.

Lycett, S. J., \& von Cramon-Taubadel, N. (2013). A 3D Morphometric Analysis of Surface Geometry in Levallois Cores: Patterns of Stability and Variability across Regions and their Implications. Journal of Archaeological Science, 40, 1508-1517. doi:10.1016/j.jas.2012.11.005.

Lycett, S. J., von Cramon-Taubadel, N., \& Eren, M. I. (2015). Levallois: Potential Implications for Learning and Cultural Transmission Capacities. Lithic Technology, (p. 160114014914008). doi:10.1179/2051618515y.0000000012.

Lycett, S. J., von Cramon-Taubadel, N., \& Foley, R. A. (2006). A Crossbeam 750 Co-ordinate Caliper for the Morphometric Analysis of Lithic Nuclei: A Description, Test and Empirical Examples of Application. Journal of Archaeological Science, 33, 847-861. doi:10.1016/j.jas.2005.10.014.

Lycett, S. J., von Cramon-Taubadel, N., \& Gowlett, J. A. J. (2010). A Comparative 3D Geometric Morphometric Analysis of Victoria West Cores: Implications for the Origins of Levallois Technology. Journal of Archaeological Science, 37, 1110-1117. doi:10.1016/j.jas.2009.12.011.

MacLeod, N. (2017). Morphometrics, History, Development Methods and Prospects. Zoological Systematics, 42, 4-33. doi:10.11865/zs. 201702.

Marcus, L. F., Corti, M., Loy, A., Naylor, G. J. P., \& Slice, D. E. 760 (1996). Advances in Morphometrics. New York: Springer. doi:10.1007/ 978-1-4757-9083-2. 
McKinnon, D. P. (2011). Foster Trailed-Incised: A GIS-Based Analysis of Caddo Ceramic Distribution. Caddo Archaeology Journal, 21, 71-88.

Mitteroecker, P., \& Gunz, P. (2009). Advances in Geometric Morphometrics. Evolutionary Biology, 36, 235-247. doi:10.1007/s11692-009-9055-x.

Okumura, M., \& Araujo, A. G. M. (2013). Pontas Bifaciais no Brasil Meridional: Caracterização Estatística das Formas e suas Implicações Culturais. Revista do Museu de Arqueologia e Etnologia, São Paulo,, 23, 111-127. doi:http: //dx.doi.org/10.11606/issn.2448-1750.revmae.2013.106842.

Okumura, M., \& Araujo, A. G. M. (2014). Long-Term Cultural Stability in Hunter-Gatherers: A Case Study using Traditional and Geometric Morphometric Analysis of Lithic Stemmed Bifacial Points from Southern Brazil. Journal of Archaeological Science, 45, 59-71. doi:10.1016/j.jas.2014.02.009.

Okumura, M., \& Araujo, A. G. M. (2017). Fronteiras Sul e Sudeste: Uma Análise Morfométrica de Pontas Bifaciais de Minas Gerais, São Paulo, Paraná e Rio Grande do Sul (Brasil). Journal of Lithic Studies, 4, in press. URL: http://journals.ed.ac.uk/lithicstudies/article/view/ 1619/2560. doi:10.2218/jls.v4i1.xxx.

Okumura, M., \& Araujo, A. G. M. (2018). Archaeology, Biology, and Borrowing: A Critical Examination of Geometric Morphometrics in Archaeology. Journal of Archaeological Science, . doi:https://doi .org/10.1016/j . jas.2017.09. 015.

Perttula, T. K. (2000). Functional and Stylistic Analyses of Ceramic Vessels from Mortuary Features at a 15th and 16th Century Caddo Site in Northeast Texas. Midcontinental Journal of Archaeology, 25, 101-151. URL: http: //www. jstor.org/stable/20708126.

Perttula, T. K. (2010). Woodland and Caddo Ceramic Traditions in East Texas. In L. W. Ellis, \& T. K. Perttula (Eds.), Regional Summaries of Prehistoric 
and Early Historic Ceramics in Texas for the Council of Texas Archeologists (pp. 13-41). Austin: Council of Texas Archeologists.

Perttula, T. K. (2015). Diversity in Ancestral Caddo Vessel Forms in East Texas Archaeological Sites. Journal of Northeast Texas Archaeology, 56, 1-19.

Perttula, T. K. (2017). Caddo Landscapes in the East Texas Forests. Havertown: Oxbow Books. URL: http://ebookcentral.proquest.com/lib/ sfasu-ebooks/detail . action?docID $=4827503$.

Picin, A., Vaquero, M., Weniger, G.-C., \& Carbonell, E. (2014). Flake Morphologies and Patterns of Core Configuration at the Abric Romaní RockShelter: A Geometric Morphometric Approach. Quaternary International, 350, 84-93. doi:10.1016/j.quaint.2014.05.004.

R Core Development Team, (2017). R: A Language and Environment for Statistical Computing. R Foundation for Statistical Computing Vienna, Austria. URL: http://www.R-project.org/.

Rezek, Z., Lin, S., Ioviţă, R., \& Dibble, H. L. (2011). The Relative Effects of Core Surface Morphology on Flake Shape and Other Attributes. Journal of Archaeological Science, 38, 1346-1359. doi:https://doi.org/10.1016/j. jas.2011.01.014.

Rice, P. M. (1991). Specialization, Standardization, and Diversity: A Retrospective. In R. L. Bishop, \& F. W. Lange (Eds.), The Ceramic Legacy of Anna O. Shepard (pp. 257-279). Niwot: University of Colorado Press.

Richtsmeier, J. T., Cheverud, J. M., \& Lele, S. (1992). Advances in Anthropological Morphometrics. Annual Review of Anthropology, 21, 283-305. doi:10.1146/annurev .an.21.100192.001435.

Rivero, D., \& Heider, G. (2017). Geometric Morphometrics in Lanceolate Projectile Points from Central Hills, Argentina. Revista del Museo de 815 Antropología, 1, 75-82. URL: https://revistas.unc.edu.ar/index.php/ antropologia/article/view/12784. 
Rohlf, F. J. (1990). Morphometrics. Annual Review of Ecology and Systematics, 21, 299-316. doi:10.1146/annurev.es.21.110190.001503.

Rohlf, F. J. (1999). Shape Statistics: Procrustes Superimpositions and Tangent Spaces. Journal of Classification, 16, 197-223. doi:10.1007/s003579900054.

Rohlf, F. J., \& Slice, D. (1990). Extensions of the Procrustes Method for the Optimal Superimposition of Landmarks. Systematic Zoology, 39, 40-59. doi:10.2307/2992207.

Rohlf, J. F., \& Marcus, L. F. (1993). A Revolution in Morphometrics. Trends in Ecology \& Evolution, 8, 129-132. doi:10.1016/0169-5347 (93) 90024-J.

Ros, J., Evin, A., Bouby, L., \& Ruas, M.-P. (2014). Geometric Morphometric Analysis of Grain Shape and the Identification of Two-Rowed Barley (Hordeum vulgare subsp. distichum L.) in Southern France. Journal of Archaeological Science, 41, 568-575. doi:https://doi.org/10.1016/j.jas. 2013.09 .015 .

Selden Jr., R. Z., Perttula, T. K., \& O'Brien, M. J. (2014). Advances in Documentation, Digital Curation, Virtual Exhibition, and a Test of 3D Geometric Morphometrics: A Case Study of the Vanderpool Vessels from the Ancestral Caddo Territory. Advances in Archaeological Practice, 2, 1-15. doi:https ://doi .org/10.7183/2326-3768.2.2.64.

Serwatka, K. (2015). Shape Variation of Middle Palaeolithic Bifacial Tools from Southern Poland: A Geometric Morphometric Approach to Keilmessergruppen Handaxes and Backed Knives. Lithics, 35, 18-32. URL: http:// journal.lithics.org/index.php/lithics/article/viewFile/371/353.

Serwatka, K., \& Riede, F. (2016). 2D Geometric Morphometric Analysis Casts Doubt on the Validity of Large Tanged Points as Cultural Markers in the European Final Palaeolithic. Journal of Archaeological Science: Reports, 9, 150-159. doi:10.1016/j.jasrep.2016.07.018. 
Shepard, A. O. (1954). Ceramics for the Archaeologist. Washington, D. C.: Publication 609, Carnegie Institution of Washington.

Sherratt, E., Gower, D. J., Klingenberg, C. P., \& Wilkinson, M. (2014). Evolution of Cranial Shape in Caecilians (Amphibia: Gymnophiona). Evolutionary Biology, 41, 528-545. URL: <GotoISI>://WOS:000344862900003. doi:https://doi .org/10.1007/s11692-014-9287-2. Flake Scar Patterns of Clovis Points Analyzed with a New Digital Morphometrics Approach: Evidence for Direct Transmission of Technological Knowledge across early North America. Journal of Archaeological Science, 39, 30183026. doi:10.1016/j.jas.2012.04.049.

Shott, M. J. (2011). History Written in Stone: Evolutionary Analysis of Stone Tools in Archeology. Evolution: Education and Outreach, 4, 435-445. doi:10. 1007/s12052-011-0344-3.

Shott, M. J., \& Trail, B. W. (2010). Exploring New Approaches to Lithic Analysis: Laser Scanning and Geometric Morphometrics. Lithic Technology, 35, 195-220. doi:http://dx.doi.org/10.1080/01977261.2010.11721090.

Slice, D. E. (2001). Landmark Coordinates Aligned by Procrustes Analysis Do Not Lie in Kendall's Shape Space. Systematic Biology, 50, 141-149. doi:10.1080/10635150119110.

Slice, D. E. (2007). Geometric Morphometrics. Annual Review of Anthropology, 36, 261-281. doi:10.1146/annurev .anthro.34.081804.120613.

Smith, H. L. (2010). A Behavioral Analysis of Clovis Point Morphology using Geometric Morphometrics. Thesis.

Smith, H. L., \& DeWitt, T. J. (2016). The Northern Fluted Point Complex: Technological and Morphological Evidence of Adaptation and Risk in the 870 Late Pleistocene-Early Holocene Arctic. Archaeological and Anthropological Sciences, . doi:DOI10.1007/s12520-016-0335-y. 
Smith, H. L., \& Goebel, T. (2018). Origins and Spread of Fluted-Point Technology in the Canadian Ice-Free Corridor and Eastern Beringia. Proceedings of the National Academy of Sciences, . URL: https://www.ncbi.nlm.nih. gov/pubmed/29610336. doi:10.1073/pnas . 1800312115.

Smith, H. L., Smallwood, A. M., \& DeWitt, T. J. (2014). A Geometric Morphometric Exploration of Clovis Fluted-Point Shape Variability. In A. M. Smallwood, \& T. A. Jennings (Eds.), Clovis: On the Edge of a New Understanding (pp. 161-180). College Station: Texas A\&M University Press.

Smith Jr., M. F. (1985). Toward an Economic Interpretation of Ceramics: Relating Vessel Size and Shape to Use. In B. A. Nelson (Ed.), Decoding Prehistoric Ceramics (pp. 254-309). Carbondale: Southern Illinois University Press.

Suhm, D. A., \& Jelks, E. B. (1962). Handbook of Texas Archeology: Type Descriptions. Austin: Bulletin Number Four. The Texas Memorial Museum.

Swanton, J. R. (1942). Source Material on the History and Ethnology of the Caddo Indians. Washington: Bulletin 132. Bureau of American Ethnology. Smithsonian Institution.

Thompson, D. W. (1917). On Growth and Form. Cambridge: Cambridge University Press.

Thulman, D. K. (2012). Discriminating Paleoindian Point Types from Florida using Landmark Geometric Morphometrics. Journal of Archaeological Science, 39, 1599-1607. doi:10.1016/j.jas.2012.01.004.

Topi, J. R., VanPool, C. S., Waller, K. D., \& VanPool, T. L. (2017). The Economy of Specialized Ceramic Craft Production in the Casas Grandes Region. Latin American Antiquity, (pp. 1-21). doi:10.1017/laq.2017.62.

Turpin, S. A., \& Neely, J. A. (1977). An Automated Computer Technique for Vessel Form Analysis. Plains Anthropologist, 22, 313-319. 
Turpin, S. A., Rabinowitz, J., Henderson, J., \& Patterson, P. E. (1976). A Statistical Examination of Caddoan Vessel Design and Shape from the Ben McKinney Site, Marion County, Texas. Plains Anthropologist, 21, 165-179.

Velhagen, W. A., \& Roth, V. L. (1997). Scaling of the Mandible in Squirrels. Journal of Morphology, 232, 107-132. doi:\{10.1002/(SICI) 1097-4687 (199705) 232:2<107: : AID- JMOR1>3. 0 . CO;2-7\}.

Wang, W., Lycett, S. J., von Cramon-Taubadel, N., Jin, J. J. H., \& Bae, C. J. (2012). Comparison of Handaxes from Bose Basin (China) and the Western Acheulean Indicates Convergence of Form, not Cognitive Differences. PLoS One, 7, e35804. URL: http://www.ncbi.nlm.nih.gov/pubmed/22536441. doi:10.1371/journal pone.0035804.

Webb, C. H. (1959). The Belcher Mound, A Stratified Caddoan Site in Caddo Parish, Louisiana volume Memoirs No. 16. Salt Lake City: Society for American Archaeology.

Webb, C. H. (1963). The Smithport Landing Site: An Alto Focus Component in DeSoto Parish, Louisiana. Bulletin of the Texas Archeological Society, 32, $143-187$.

Webb, C. H. (1996). Gift of Dr. Clarence Webb.

Webb, C. H., \& Dodd, J., M. (1939). Further Excavations of the Gahagan Mound: Connections with a Florida Culture. Bulletin of the Texas Archeological and Paleontological Society, 11, 92-126.

Webb, C. H., \& Dodd Jr., M. (1941). Pottery Types from the Belcher Mound Site. Bulletin of the Texas Archeological and Paleontological Society, 13, 88116.

Wilczek, J., Monna, F., Barral, P., Burlet, L., Chateau, C., \& Navarro, N. (2014). Morphometrics of Second Iron Age Ceramics - Strengths, Weaknesses, and Comparison with Traditional Typology. Journal of Archaeological 925 Science, 50, 39-50. doi:10.1016/j.jas.2014.05.033. 
Wilczek, J., Monna, F., Gabillot, M., Navarro, N., Rusch, L., \& Chateau, C. (2015). Unsupervised Model-Based Clustering for Typological Classification of Middle Bronze Age Flanged Axes. Journal of Archaeological Science: Reports, 3, 381-391. doi:https://doi.org/10.1016/j.jasrep.2015.06.030.

Wills, M. A. (2001). Morphological Disparity: A Primer. In J. M. Adrain, G. D. Edgecombe, \& B. S. Lieberman (Eds.), Fossils, Phylogeny, and Form. Topics in Geobiology, Vol. 19.. Boston: Springer. doi:https://doi.org/10.1007/ 978-1-4615-0571-6_4.

Windhager, S., Bookstein, F. L., Grammer, K., Oberzaucher, E., Said, H., Slice, D. E., Thorstensen, T., \& Schaefer, K. (2012). "Cars Have their own Faces": Cross-Cultural Ratings of Car Shapes in Biological (Stereotypical) Terms. Evolution and Human Behavior, 33, 109-120. doi:10.1016/j . evolhumbehav.2011.06.003.

Zelditch, M. L., Swiderski, D. L., Sheets, H. D., \& Fink, W. L. (2004). Geometric Morphometrics for Biologists : A Primer. Burlington: Elsevier Science. URL: http://ebookcentral.proquest.com/lib/tamucs/detail. action?docID=298308. 